\title{
Obesity and cancer: mechanistic insights from transdisciplinary studies
}

\author{
Emma H Allott ${ }^{1,2}$ and Stephen D Hursting ${ }^{2,3}$ \\ 'Department of Epidemiology, CB 7435, University of North Carolina at Chapel Hill, 135 Dauer Drive, \\ Chapel Hill, North Carolina 27599, USA \\ ${ }^{2}$ Lineberger Comprehensive Cancer Center, University of North Carolina at Chapel Hill, 135 Dauer Drive, \\ Chapel Hill, North Carolina 27599, USA \\ ${ }^{3}$ Department of Nutrition, University of North Carolina at Chapel Hill, 135 Dauer Drive, Chapel Hill, \\ North Carolina 27599, USA
}

\author{
Correspondence \\ should be addressed \\ to E H Allott \\ Email \\ allott@email.unc.edu
}

\begin{abstract}
Obesity is associated with a range of health outcomes that are of clinical and public health significance, including cancer. Herein, we summarize epidemiologic and preclinical evidence for an association between obesity and increased risk of breast and prostate cancer incidence and mortality. Moreover, we describe data from observational studies of weight change in humans and from calorie-restriction studies in mouse models that support a potential role for weight loss in counteracting tumor-promoting properties of obesity in breast and prostate cancers. Given that weight loss is challenging to achieve and maintain, we also consider evidence linking treatments for obesity-associated co-morbidities, including metformin, statins and non-steroidal anti-inflammatory drugs, with reduced breast and prostate cancer incidence and mortality. Finally, we highlight several challenges that should be considered when conducting epidemiologic and preclinical research in the area of obesity and cancer, including the measurement of obesity in population-based studies, the timing of obesity and weight change in relation to tumor latency and cancer diagnosis, and the heterogeneous nature of obesity and its associated co-morbidities. Given that obesity is a complex trait, comprised of behavioral, epidemiologic and molecular/metabolic factors, we argue that a transdisciplinary approach is the key to understanding the mechanisms linking obesity and cancer. As such, this review highlights the critical need to integrate evidence from both epidemiologic and preclinical studies to gain insight into both biologic and non-biologic mechanisms contributing to the obesity-cancer link.
\end{abstract}

\footnotetext{
Key Words

- aspirin

- breast cancer

- cholesterol

- epidemiology

- insulin

- prostate cancer

- mechanisms

- metformin

- mouse models

- NSAIDs

- obesity

- screening

- statins

- transdisciplinary

- weight loss
}

Endocrine-Related Cancer (2015) 22, R365-R386

\section{Introduction}

Cancer is predicted to overtake heart disease as the leading cause of death across all age groups in the U.S. by 2030, translating to a $45 \%$ increase in the number of cancer diagnoses in the next 15 years (American Society of Clinical Oncology 2014). Global obesity prevalence has been increasing by approximately half a BMI unit per decade over the past three decades, resulting in over 600 million adults worldwide with a BMI of $30 \mathrm{~kg} / \mathrm{m}^{2}$ or greater (Finucane et al. 2011, Stevens et al. 2012). With more than one in three U.S. adults classified as obese, the prevalence of obesity in the country is currently the highest in the Western world (Finucane et al. 2011, Ogden et al. 2014). 
Obesity is associated with increased risk of a variety of different cancer types (World Cancer Research Fund 2007). Of these obesity-associated cancer types, almost $13 \%$ of incident cases worldwide, and $\sim 20 \%$ of incident cases in Europe and North America, are attributable to obesity (Arnold et al. 2014). Furthermore, it is estimated that one quarter of these cases could have been avoided had the worldwide obesity prevalence not approximately doubled since 1980 (Arnold et al. 2014). Excess weight and obesity also drive cancer progression, and have been estimated to account for $14 \%$ of all cancer deaths in men and $20 \%$ in women in the United States (Calle et al. 2003), while 6\% of cancer deaths around the same time period in Europe were attributable to obesity (Banegas et al. 2003).

Cancers of the breast and prostate are among the most commonly diagnosed and among the leading causes of cancer deaths in women and men, respectively, both in the U.S. and worldwide (Jemal et al. 2011, Siegel et al. 2015). Therefore, understanding mechanisms linking obesity and risk of these common tumor types will be important for cancer prevention efforts worldwide. In addition, of over 11 million U.S. individuals living with cancer, survivors of breast cancer constitute the largest group $(22 \%)$, followed by survivors of prostate cancer (19\%) (Centers for Disease Control \& Prevention 2011). Therefore, understanding mechanisms linking obesity and cancer progression in these common tumor types has great importance for a large proportion of cancer survivors, and will likely also benefit survivors of other obesity-associated cancer types. Molecular mechanisms linking obesity and cancer have been reviewed in depth elsewhere (Allott et al. 2013a, Ford et al. 2013a, Lashinger et al. 2014a). As such, this review adopts a transdisciplinary approach, summarizing findings from both epidemiologic and preclinical studies (Fig. 1), in addition to examining evidence for the modifiable nature of obesity and related co-morbidities through weight loss and pharmacologic interventions in both humans and mouse models. Finally, we consider how a transdisciplinary approach can minimize the weaknesses and maximize the strengths of each discipline, enabling a deeper understanding of mechanisms linking obesity and cancer.

\section{Transdisciplinary insights into associations between obesity and cancer}

\section{Obesity and breast cancer}

The association between obesity and breast cancer risk is complex, varying by menopausal status and by breast

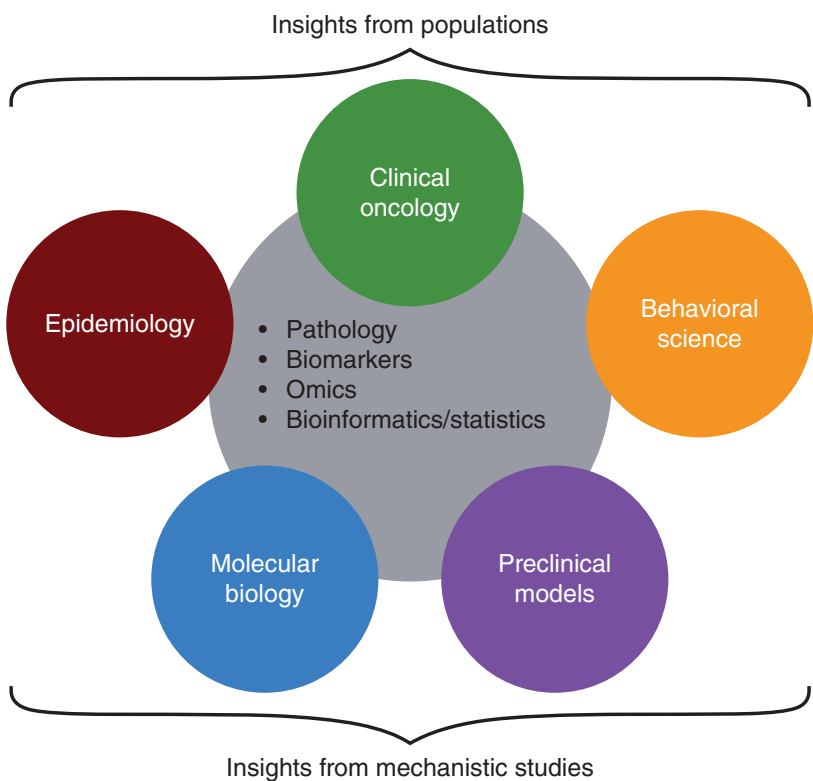

Figure 1

Using a transdisciplinary approach to study mechanisms linking obesity and cancer.

cancer subtype. Obesity is associated with reduced breast cancer incidence in premenopausal women (World Cancer Research Fund 2007), but increased breast cancer incidence in postmenopausal women (World Cancer Research Fund 2007, Munsell et al. 2014), although the association with postmenopausal breast cancer is attenuated in women using hormone replacement therapy (Munsell et al. 2014). While these contrasting associations by menopausal status are consistently reported, differences in these associations by hormone receptor status are less well understood. Within postmenopausal breast cancers, there is a suggestion that the association with obesity is strongest among hormone receptorpositive cases (Althuis et al. 2004, Rosenberg et al. 2006, Suzuki et al. 2009, Canchola et al. 2012), although other studies did not find differences in these associations by breast cancer subtype (Millikan et al. 2008, Phipps et al. 2008, Yang et al. 2011). Several studies have reported that, although obesity is a protective factor for total premenopausal breast cancer, it is associated with increased risk of triple negative and basal-like disease in premenopausal women (Millikan et al. 2008, Gaudet et al. 2011, Yang et al. 2011). Interestingly, some evidence suggests that obesity may be a risk factor for basal-like breast cancer regardless of menopausal status (Millikan et al. 2008), suggesting a role for non-hormonal mechanisms in basal-like breast cancer pathogenesis.

Published by Bioscientifica Ltd. 
While the association between obesity and breast cancer risk differs by menopausal status, obesity is associated with increased risk of breast cancer recurrence and mortality in both pre and postmenopausal women (Niraula et al. 2012, Chan et al. 2014). While several studies have suggested that this association may be stronger among women with hormone receptor-positive tumors (Sparano et al. 2012, Jiralerspong et al. 2013, Azrad \& Demark-Wahnefried 2014, Tait et al. 2014), others reported no difference in the association between obesity and breast cancer-specific mortality by subtype (Phipps et al. 2008, Niraula et al. 2012). However, partial availability of subtype data and lower numbers of patients with rarer breast cancer subtypes is a limitation for many studies (Althuis et al. 2004). Given the evidence for etiologic heterogeneity of breast cancer, understanding the obesity-breast cancer link in humans requires large, well-annotated studies with sufficient power to conduct stratified analysis both by menopausal status and subtype.

The recognition of breast cancer as a heterogeneous disease has led to the characterization of mouse models that reflect human breast cancer subtypes (Herschkowitz et al. 2007). One particular challenge of preclinical models of breast cancer is that the estrogen receptor (ER) is weakly expressed in most mouse mammary tumors, particularly in genetically-engineered mice, and thus murine models of hormone receptor-positive breast cancer may not be fully representative of human luminal breast cancer (Herschkowitz et al. 2007, Borowsky 2011). Nonetheless, diet-induced obesity has been demonstrated to drive tumor growth in a variety of mouse models with both luminal (Pape-Ansorge et al. 2002, Ford et al. 2013b) and basal-like tumor characteristics (Dogan et al. 2007, Hakkak et al. 2007, Dunlap et al. 2012, Giles et al. 2012, Nogueira et al. 2012, Sundaram et al. 2013), lending support to epidemiologic observations. In contrast, there is little preclinical support for links between obesity and luminal B or HER-2 breast cancer subtypes (Cleary et al. 2004, Ford et al. 2013b), although the degree to which these models are representative of these human subtypes is unclear. Finally, one study showed that diet-induced obesity enhanced the growth of luminal-like tumors in ovariectomized mice but not in mice with intact ovaries (Nunez et al. 2008), suggesting that the relationship between obesity and postmenopausal luminal breast cancer should be tested in ovariectomized mice in order to model the human postmenopausal environment. However, given epidemiologic evidence supporting an association between obesity and basal-like breast cancer regardless of menopausal status, the relevance of ovariectomization to study the impact of diet-induced obesity on basal-like breast cancer in mouse models is less clear.

\section{Obesity and prostate cancer}

Although individual studies are conflicted regarding the association between obesity and prostate cancer risk, a number of large meta-analyses have reported that obesity is associated with a modestly elevated total prostate cancer incidence (Bergstrom et al. 2001, MacInnis \& English 2006, Renehan et al. 2008, Hu et al. 2014). One metaanalysis demonstrated that findings from the individual contributing studies differed by geographic region (Renehan et al. 2008), thereby offering insight into these somewhat conflicted results. Prostate-specific antigen (PSA) levels are reduced in obese men via hemodilution (Banez et al. 2007), thereby lowering the likelihood of a PSA-driven biopsy and giving rise to an obesity-associated detection bias. This bias becomes apparent when comparing the results of U.S. studies where PSA screening is widespread, with the results of European studies where PSA screening is less common (Renehan et al. 2008). In the U.S., where prostate biopsies are largely driven by PSA screening, obese men have a reduced chance of undergoing biopsy compared to normal-weight men, leading to the detection of fewer cancers in obese individuals and biasing the association between obesity and prostate cancer towards the null. In countries with lower PSA screening rates, such as Europe and Australia, this detection bias is reduced and the meta-analysis of studies from these regions demonstrates a positive association between obesity and prostate cancer risk (Renehan et al. 2008). These data highlight the importance of considering how the association between obesity and prostate cancer risk is impacted by the mode of cancer detection, particularly in the context of changing PSA screening recommendations in the U.S. (Moyer and U.S. Preventative Services Task Force 2012).

While the association between obesity and total prostate cancer is complicated by obesity-associated detection bias, there is consistent and convincing evidence for an association between obesity and elevated risk of aggressive prostate cancer (Rodriguez et al. 2007, Zhang et al. 2015). Furthermore, multiple large studies, both before and after the introduction of widespread PSA screening in the U.S., demonstrated an association between obesity and increased prostate cancer-specific mortality (Andersson et al. 1997, Rodriguez et al. 2001, Wright et al. 2007, Cao \& Ma 2011, Zhang et al. 2015), indicating that obesity-associated detection bias does not

Published by Bioscientifica Ltd. 
completely explain the association between obesity and prostate cancer, but that biologic mechanisms must also play a role.

Consistent with epidemiologic evidence for an association between obesity and tumor aggressiveness and progression, tumor growth in mouse models of prostate cancer has been shown to be responsive to obesity. A number of studies have demonstrated a role for dietinduced obesity in promoting prostate tumor growth in the transgenic adenocarcinoma of the prostate (TRAMP) mouse model (Llaverias et al. 2010, Bonorden et al. 2012). In addition, diet-induced obesity reduced tumor latency in the Hi-Myc mouse model, via increased Akt/mTOR signaling (Kobayashi et al. 2008, Blando et al. 2011), and promoted tumor progression in a transgenic mouse model with PTEN haploinsufficiency, via increased inflammatory and insulin signaling pathways (Liu et al. 2015). These transgenic models may have relevance to the human prostate cancer, given that the Myc copy number is amplified in up to one third of human prostate cancers (Ellwood-Yen et al. 2003) and PTEN loss is the most common genetic alteration in human prostate cancer (Wang et al. 2003).

\section{Non-biologic mechanisms contributing to the obesity - cancer link}

\section{Obesity and cancer screening}

Evidence suggests that obesity-associated screening and detection biases may act to delay cancer diagnosis, thereby increasing cancer-specific mortality in obese patients
(Fig. 2). Obese individuals may be less likely to participate in screening programs, which could contribute to delayed cancer diagnosis, an association shown to be modified by the type of screening test, by race and by gender (Fagan et al. 2011). Indeed, mammography screening rates are reduced by as much as $10 \%$ in obese (BMI $\geq 30 \mathrm{~kg} / \mathrm{m}^{2}$ ) and $20 \%$ in morbidly obese (BMI $\geq 40 \mathrm{~kg} / \mathrm{m}^{2}$ ) women (Maruthur et al. 2009), and while the reasons for reduced participation in cancer screening are not completely understood, they may include modesty, pain, and/or competing healthcare demands (Friedman et al. 2012).

In contrast to the associations with breast cancer screening, an inverse association between obesity and PSA screening frequency has been reported in prostate cancer, with obese men being screened more frequently than their normal-weight counterparts (Scales et al. 2007). However, obesity is associated with a reduced likelihood of prostate cancer diagnosis in a screened population despite higher PSA screening frequency in obese men, suggesting that obesity may decrease screening effectiveness in some cancer types. In obese prostate cancer patients, their larger body size and bigger prostate make conducting a digital rectal exam more challenging (Chu et al. 2011), and a large prostate may reduce the likelihood of finding the cancer at biopsy (Freedland et al. 2006). This is also true for other cancer types; mammography is anecdotally more difficult in obese patients (Amy et al. 2006), potentially delaying cancer diagnosis even in screened obese individuals. Indeed, obesity has been associated with a higher stage at breast cancer diagnosis (Cui et al. 2002), suggesting that obese women may be diagnosed later in the course of their disease. However, another study reported this finding

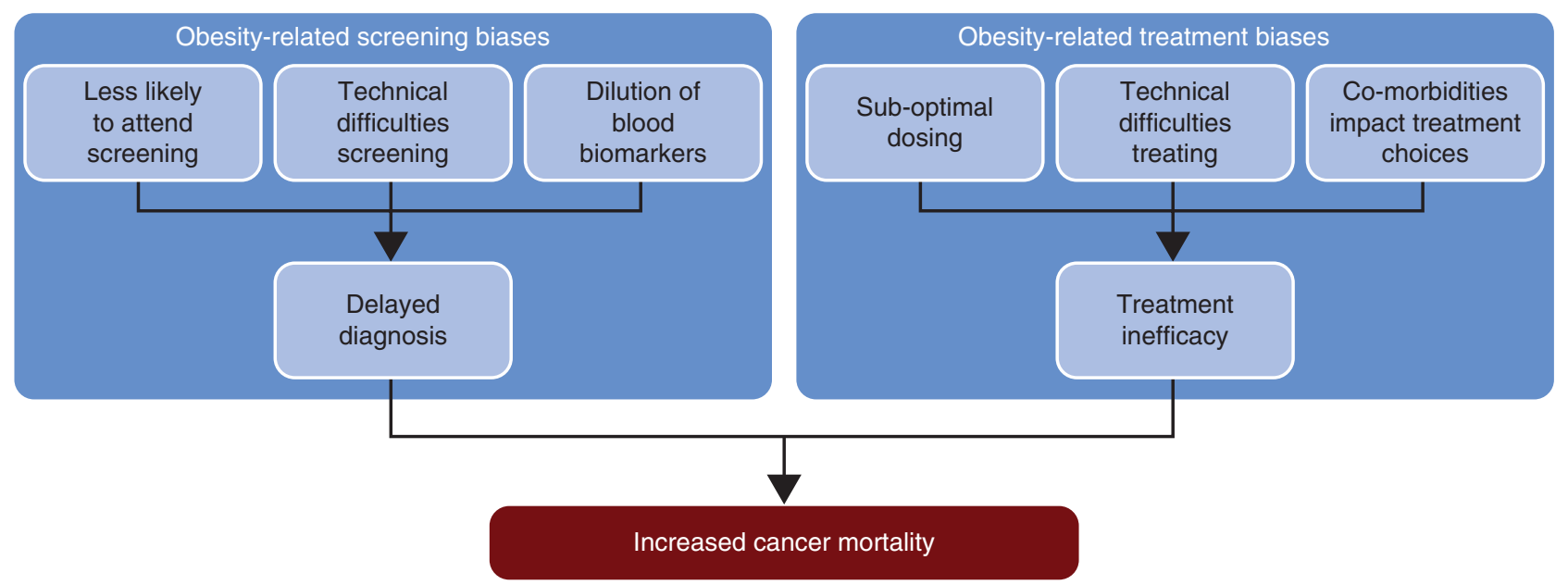

Figure 2

Non-biologic mechanisms linking obesity and cancer mortality. 
regardless of mammography screening frequency, suggesting that the association between obesity and high-stage breast cancer may not simply be a result of lower screening rates in this population (Kerlikowske et al. 2008), but that biologic mechanisms must also play a role.

Finally, the larger blood volume in obese individuals has been associated with biomarker hemodilution, as has been suggested in PSA-detected prostate cancer (Banez et al. 2007). Several studies have estimated that PSA levels are reduced by $\sim 15 \%$ in cancer-free morbidly obese (BMI $\geq 35 \mathrm{~kg} / \mathrm{m}^{2}$ ) men, while PSA mass (i.e., the absolute quantity of PSA in the blood) is not associated with obesity status (Grubb et al. 2009, Rundle \& Neugut 2009). Lower biomarker levels in obesity reduce the likelihood of reaching biopsy thresholds, potentially contributing to delayed diagnosis in obese individuals.

\section{Obesity and cancer treatment}

In addition to biologic mechanisms (reviewed in Lashinger et al. (2014b)), non-biologic factors also contribute to the reduced treatment efficacy in obese patients (Fig. 2). There is considerable evidence to suggest that obese cancer patients are undertreated with systemic therapies (Lyman \& Sparreboom 2013), and this may negatively impact cancer outcomes. Traditionally, chemotherapy dosing is based upon the body surface area (BSA) of the patient. However, there is uncertainty regarding dosing of obese patients and evidence that dose reduction occurs in this population, either because an idealized body weight is used to calculate BSA, or because BSA is arbitrarily capped due to toxicity concerns (Lyman et al. 2003). Current clinical guidelines for chemotherapy dosing in obese patients indicate that weight-based chemotherapy doses should be given and that dose should not be reduced for obese patients (Griggs et al. 2012). As such, it is recommended that any modifications to the dose due to toxicity concerns or presence of co-morbidities should be made independently of the patient's obesity status (Lyman \& Sparreboom 2013).

In prostate cancer, obesity is associated with increased daily prostate shift, rendering external beam radiation treatment more technically challenging, and potentially contributing to increased rates of treatment failure in obese patients (Merrick et al. 2007). Technical difficulties applying the adequate radiation dose to the correct area in obese patients has also been suggested in breast cancer (Carmichael \& Bates 2004). In addition to these potential difficulties with radiation therapy, obese patients may also be less likely to make good surgical candidates. In prostate cancer, obesity has been shown to be associated with capsular incision, reflecting a less-than-ideal operation (Freedland et al. 2005). However, even when focusing solely on patients with organ-confined disease and negative surgical margins, obesity remains associated with biochemical recurrence following radical prostatectomy, implying that obesity is associated with disease progression in prostate cancer through mechanisms other than how it may affect surgical technique (Freedland et al. 2004).

Obesity and related co-morbidities are associated with an increased risk of adverse treatment effects, which may impact the treatment plan (Schmitz et al. 2013). In breast cancer, obesity has been associated with a higher risk of lymphedema, in addition to other treatment-related side effects (Togawa et al. 2014). Obese, diabetic breast cancer patients undergoing chemotherapy have increased likelihood of side effects, including infection and chemotherapy-related toxicity (Srokowski et al. 2009). In addition, cytotoxic therapy has been associated with treatment-related weight gain and metabolic syndrome in breast cancer patients (Bicakli et al. 2014, Makari-Judson et al. 2014), potentially exacerbating these aforementioned side effects. In prostate cancer, obesity is associated with weight gain and increased risk of diabetes following androgen deprivation therapy (Keto et al. 2011, Tsai et al. 2014), particularly among older men (Morgans et al. 2014). Given that more men diagnosed with prostate cancer die from cardiovascular disease than from prostate cancer (Allott et al. 2013a), this relationship has important implications for prostate cancer survivors.

Finally, excess body weight has been linked to altered metabolism of cytotoxic drugs and therapies, potentially via a number of mechanisms, including altered levels of circulating growth factors, hormones and cytokines (Rodvold et al. 1988, Litton et al. 2008). Despite evidence that aromatase inhibitors may not be as efficacious in obese breast cancer patients (Wolters et al. 2012, Azrad \& Demark-Wahnefried 2014, Ioannides et al. 2014), standard doses are given irrespective of BSA or body size (Goodwin $\&$ Pritchard 2010). In contrast, response to tamoxifen has not been shown to differ by obesity status (Wolters et al. 2012), and no differences in ER-positive breast cancer recurrence rates by obesity status have been reported following tamoxifen treatment (Dignam et al. 2003). Finally, one trial suggested that obese breast cancer patients treated with chemotherapy had reduced diseasefree survival relative to normal weight patients, even after controlling for other prognostic factors (de Azambuja et al. 2010). In prostate cancer, obesity at the time of androgen

Published by Bioscientifica Ltd 
deprivation therapy is associated with an increased risk of castrate-resistant prostate cancer, metastasis and prostate cancer-specific mortality (Keto et al. 2011). Although the exact explanation for this is unclear, one study found that testosterone levels in obese men on androgen deprivation therapy were higher, suggesting inadequate testosterone suppression (Smith 2007). It has been hypothesized that this may be because the amount of gonadotropinreleasing hormone analogue given is the same regardless of BSA, and thus obese men may be under-dosed. However, while these non-biological factors must be considered, they cannot completely explain the association between obesity and cancer mortality, and biologic mechanisms must also contribute (Lashinger et al. 2014b).

\section{Obesity and related co-morbidities as modifiable lifestyle factors}

\section{Weight gain and loss}

Evidence for the association between obesity and cancer is substantiated by studies showing that weight change can impact both risk and survival for obesity-associated cancers (Fig. 3). Bariatric procedures to cause weight loss have been associated with reduced risk of obesityassociated cancer types and a 40-50\% decrease in cancerspecific mortality across cancer types (Sjostrom et al. 2007, Adams et al. 2009), suggesting that weight loss may be an

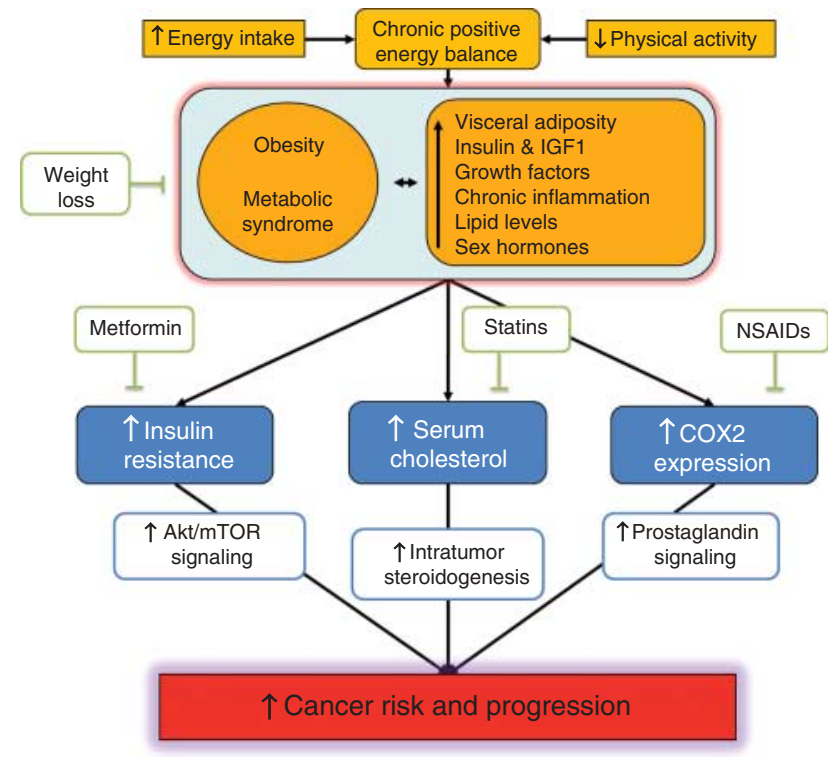

Figure 3

Putative mechanisms linking obesity with cancer risk and progression: lessons from studies of chemopreventive agents. effective chemopreventive strategy in obese individuals (Ashrafian et al. 2011). Interestingly, one prospective intervention trial suggested that bariatric procedures may be more effective at decreasing cancer risk in women, compared to men (Sjostrom et al. 2009), although these results should be interpreted with caution given the smaller sample size of males and mean follow-up time of only one decade, which may not be a long enough latency period for certain cancer types to manifest (Renehan 2009). Aside from these studies of bariatric patients, the majority of the evidence supporting a role for weight change in cancer incidence and mortality comes from secondary analyses of observational studies. Of note, the most common pattern of weight change over time is consistent weight gain throughout adulthood (Harvie et al. 2005), and therefore statistical power to study the impact of weight loss is often limited.

Adult weight gain is associated with increased risk of postmenopausal breast cancer (Eliassen et al. 2006), with a suggestion of a stronger association for hormone receptorpositive breast cancer (Eliassen et al. 2006, Vrieling et al. 2010). Furthermore, adult weight gain prior to diagnosis is associated with increased mortality from postmenopausal breast cancer (Cleveland et al. 2007). Conversely, weight loss during adulthood, whether before or after menopause, has been associated with decreased risk of postmenopausal breast cancer (Harvie et al. 2005, Eliassen et al. 2006), again with the strongest inverse associations for hormone receptor-positive breast cancer (Eliassen et al. 2006). While clinical trials to formally examine the impact of weight loss on breast cancer-specific mortality have not yet been conducted, two trials in breast cancer survivors reported that weight loss of $>10 \%$ of body mass can be achieved in this population (Befort et al. 2012, Goodwin et al. 2014). Furthermore, a weight loss intervention in cancer-free postmenopausal women suggested that $10 \%$ weight loss is sufficient to positively impact biomarker levels associated with breast cancer in both serum and benign breast tissue (Fabian et al. 2013), indicating that such an intervention may be both feasible and worthwhile (Irwin 2014).

Evidence from mouse models of breast cancer showing that weight loss impacts tumor growth supports these epidemiologic data. Weight loss can be achieved in mouse models by calorie restriction (CR), a $20-40 \%$ reduction in total energy intake relative to a control group fed ad libitum, arguably one of the most potent dietary regimens for suppressing carcinogenesis (Hursting et al. 2010). Despite the suggestion of stronger epidemiologic associations between weight change and hormone

Published by Bioscientifica Ltd 
receptor-positive breast cancer, CR slows tumor growth in mouse models regardless of tumor subtype (Pape-Ansorge et al. 2002, Dunlap et al. 2012, Nogueira et al. 2012, Ford et al. 2013b, Mizuno et al. 2013), providing rationale to study the impact of weight loss across breast cancer subtypes in humans. Mechanistic insights from these models have highlighted Akt/mTOR signaling and the insulin/insulin-like growth factor (IGF) 1 axis as two protumor pathways upregulated by obesity and reversed by CR (Hursting et al. 2010). Interestingly, a protective effect of intermittent CR on tumor growth has also been reported (Rogozina et al. 2013), and this dietary regimen may be more feasible and appealing to humans. While the majority of preclinical studies randomize mice to CR from the outset, two preclinical studies have specifically tested the impact of diet-induced obesity followed by weight loss, by incorporating a diet switch during the intervention period. Interestingly, these studies reported contrasting findings, with one reporting that weight loss reversed the tumor-promoting effect of obesity (Sundaram et al. 2014a), and the other reporting that weight loss did not impact obesity-fueled tumor growth (De Angel et al. 2013). Key differences between studies included the degree of obesity attained by the mice and the timing and duration of weight loss, in addition to the use of two different mouse models of basal-like breast cancer, one xenograft (De Angel et al. 2013) and the other transgenic (Sundaram et al. 2014a). Discrepant findings such as these may shed light on mechanisms linking weight loss and breast cancer, in addition to informing future study design in both preclinical mouse models and humans.

Retrospective analyses of large cohort studies have also revealed inverse associations between weight loss and prostate cancer incidence and mortality. Relative to weight maintenance, adult weight gain is associated with an increased risk of aggressive prostate cancer (Bassett et al. 2011), while adult weight loss is associated with reduced risk of aggressive prostate cancer (Rodriguez et al. 2007). Furthermore, some large prospective cohort studies have reported that weight gain in adulthood is associated with increased prostate cancer-specific mortality (Wright et al. 2007, Bassett et al. 2011), although others reported no association between adult weight change and prostate cancer-specific mortality (Chamberlain et al. 2011, Moller et al. 2013). Studies focused on weight change within the decade of prostate cancer diagnosis report more consistent findings, with weight gain in the 5-year time period preceding diagnosis associated with increased risk of recurrence (Joshu et al. 2011, Whitley et al. 2011), and weight gain in the 5-year time period following diagnosis associated with an increased risk of prostate cancerspecific mortality (Bonn et al. 2014).

While evidence for a role for weight loss in counteracting tumor growth in mouse models of prostate cancer is relatively sparse, a tumor-inhibitory effect of CR has been demonstrated via reduced insulin/IGF1 levels and increased tumor apoptosis in a xenograft mouse model (Galet et al. 2013), although this effect has not been reported in all xenograft models (Buschemeyer et al. 2010, Thomas et al. 2010). In addition, one study demonstrated that CR slowed progression to adenocarcinoma in the $\mathrm{Hi}$-Myc transgenic mouse model of prostate cancer, via reduced prostate inflammation and inhibition of Akt/ mTOR signaling (Blando et al. 2011). CR has also been demonstrated to impact tumor growth in the TRAMP model, with intermittent $\mathrm{CR}$ having a greater impact than chronic CR (Bonorden et al. 2009), although a role for intermittent CR has not been supported by other prostate cancer studies (Buschemeyer et al. 2010, Thomas et al. 2010).

Given the challenges surrounding compliance with $\mathrm{CR}$ and maintenance of weight loss in humans, alternative strategies are also worth exploring. Intermittent CR is one such strategy, and while one randomized weight loss trial in women showed that both intermittent and chronic CR caused weight loss and improved insulin sensitivity and cytokine profile (Harvie et al. 2011), avoiding weight gain may remain the most sensible approach both for general health and chemoprevention (Thompson \& McTiernan 2011). Alternatively, understanding the mechanisms by which CR increases tumor latency and slows tumor progression may help identify CR mimetics with chemopreventive properties (reviewed in (Hursting et al. 2010)).

\section{Pharmaceuticals}

Type II diabetes and metformin Type II diabetes currently affects $\sim 15 \%$ of the adult population in the U.S., and the prevalence of this obesity-associated co-morbidity is on the increase (Boyle et al. 2010). Epidemiologic data support an association between diabetes and an increased risk of certain cancer types, including breast cancer (Larsson et al. 2007, Giovannucci et al. 2010, De Bruijn et al. 2013, Tsilidis et al. 2015a). Although not all studies have reported subtype-specific differences in this association (Campos-Gomez et al. 2014), there is some evidence that the association between diabetes and breast cancer risk may be stronger in postmenopausal women (Michels et al. 2003, Larsson et al. 2007) and for hormone receptorpositive breast cancer (Michels et al. 2003). In addition,

Published by Bioscientifica Ltd. 
a meta-analysis of clinical trials and prospective cohort studies reported that diabetes is associated with increased breast cancer-specific mortality, although subtype was not examined (De Bruijn et al. 2013). In direct contrast to the positive association with breast cancer risk, there is an inverse association between diabetes and total prostate cancer incidence (Kasper \& Giovannucci 2006, Zhang et al. 2012). Temporal analysis has demonstrated that longer duration of diabetes is more protective for total prostate cancer risk (Kasper et al. 2009, Tsilidis et al. 2015b), suggesting that the metabolic and hormonal environment of advanced/end-stage diabetes, characterized by reduced bioavailable testosterone and low insulin, is consistent with protection from total prostate cancer incidence (Kasper \& Giovannucci 2006, Allott et al. 2013b). However, longer duration of diabetes in obese men was associated with increased risk of metastasis following radical prostatectomy (Wu et al. 2013), and diabetes has been associated with an increased risk of prostate cancer-specific mortality (Cai et al. 2014), suggesting that the low-insulin environment of advanced diabetes may select for more aggressive prostate cancers that can survive in this environment (Allott et al. 2013b). Therefore, while associations with diabetes are contrasting for breast and prostate cancer incidence, associations with cancer progression and mortality are consistent for both tumor types.

Relative to other anti-diabetic therapies, metformin has been associated with reduced total cancer incidence in some (Evans et al. 2005, Decensi et al. 2010), but not all studies (Tsilidis et al. 2014), and with decreased cancerspecific mortality (Currie et al. 2012, Lega et al. 2014). In line with these findings, evidence supporting a role for metformin in breast cancer is somewhat mixed. A metaanalysis reported that metformin use was associated with reduced breast cancer incidence and mortality (Zhang et al. 2013), but other studies failed to demonstrate a protective effect of metformin on breast cancer incidence (Franciosi et al. 2013, Tsilidis et al. 2014, Kowall et al. 2015) or mortality (Lega et al. 2014). Furthermore, there is inconsistent evidence for differences in these associations by breast cancer subtype, with one study reporting a larger proportion of progesterone receptor-positive tumors in metformin users vs non-users (Berstein et al. 2011), while another study did not find any difference in the frequency of hormone receptor-positive tumors by metformin use (Besic et al. 2014). A trial in which women were randomized to metformin 1 month prior to breast cancer surgery found that metformin use reduced Ki67 expression in HER2-positive resected tumors (DeCensi et al. 2014), while another study reported that metformin use was associated with reduced HER2-positive breast cancerspecific mortality (He et al. 2012). In support of these epidemiologic data, preclinical data show that metformin suppressed overexpression of the HER2 protein via Akt/mTOR pathway inhibition (Vazquez-Martin et al. 2009), and delayed the onset of adenocarcinoma in a transgenic mouse model of HER2-positive breast cancer (Anisimov et al. 2010). However, metformin has also been shown to slow tumor growth in an ER-positive mouse model of breast cancer, via suppression of obesityassociated adipokine levels and reduced Akt/mTOR pathway activation (Fuentes-Mattei et al. 2014), suggesting that the potential chemopreventive effect of metformin may not be limited to HER2-positive tumors. Finally, a preclinical study reported that metformin does not impact tumor growth in nondiabetic rat and mouse models (Thompson et al. 2015), a finding supported by epidemiologic data that metformin impacts Ki67 tumor expression in insulin-resistant but not in insulin-sensitive women (DeCensi et al. 2014).

In prostate cancer, although some studies report inconsistent findings (Murtola et al. 2008, Currie et al. 2009, Wright \& Stanford 2009, Azoulay et al. 2011, Franciosi et al. 2013), mounting evidence supports an inverse association between metformin use and prostate cancer risk in men with diabetes (Clyne 2014, Preston et al. 2014, Yu et al. 2014a). Fewer studies have examined the association between metformin use and prostate cancer recurrence and mortality, with somewhat mixed results. While several individual studies reported null findings (Patel et al. 2010, Allott et al. 2013b, Kaushik et al. 2013), a meta-analysis demonstrated that metformin use was associated with reduced risk of recurrence following primary therapy (Yu et al. 2014a), and there is evidence to support an inverse association between metformin use and prostate cancer-specific mortality (Margel et al. 2013, Bensimon et al. 2014), although this has not been reported by all studies (Lega et al. 2014). Further supporting a chemopreventive role for metformin in prostate cancer, metformin slowed tumor growth in a xenograft mouse model of prostate cancer (Ben Sahra et al. 2008), in addition to reducing IGF1 levels and modestly counteracting the tumor-promoting properties of a high-fat diet in a small study using the TRAMP model (Xu et al. 2014). Finally, metformin reduced mouse prostatic intraepithelial neoplasia (mPIN) development and slowed transition to adenocarcinoma in the Hi-Myc transgenic mouse model of prostate cancer, via downregulation of $M y c$ gene expression (Akinyeke et al. 2013).

Published by Bioscientifica Ltd. 
While data from both preclinical and populationbased studies support an antineoplastic role for metformin, translating findings from laboratory studies to humans is rendered more challenging by high metformin doses commonly used in animal and cell-based models, often exceeding recommended therapeutic doses in humans (Ben Sahra et al. 2010). In addition, the progressive nature of diabetes and the various medications used to control it makes population-based research into the impact of metformin on cancer risk and mortality somewhat challenging. Time-related biases are a consideration in observational studies of drug use and may lead to overestimation of the inverse association between metformin and cancer (Suissa \& Azoulay 2012). However, a metaanalysis of prospective studies that controlled for obesity status and that were not subject to time-related biases concluded that metformin was associated with a modest reduction in overall cancer risk (Gandini et al. 2014). Whether metformin should be considered as a chemopreventive agent for individuals without diabetes is another issue. Preclinical studies have demonstrated direct action of metformin on cancer cells through AMPK activation and mTOR signaling (Zhou et al. 2001, Hardie $\&$ Alessi 2013), suggesting that metformin may also have chemopreventive properties in individuals without insulin resistance or diabetes. However, a body of evidence in both population and preclinical mouse models suggests that metformin impacts tumor growth only in the context of insulin resistance, obesity and/or diabetes, indicating that improving insulin sensitivity may be a key indirect mechanism by which metformin impacts cancer growth (Bonanni et al. 2012, DeCensi et al. 2014, Thompson et al. 2015). This proposed mechanism is further supported by evidence linking elevated levels of C-peptide (a surrogate for insulin levels) with breast and prostate cancer-specific mortality (Ma et al. 2008, Goodwin et al. 2012). Therefore, while evidence suggests that metformin may be most beneficial for preventing cancer growth in insulinresistant individuals via indirect mechanisms, future studies should explore potential direct mechanisms using preclinical models and metformin doses that reflect those used in humans.

Inflammation and non-steroidal anti-inflammatory drugs Chronic, low-grade inflammation is a hallmark of obesity, and has been proposed as a mechanistic link between obesity and cancer (Colotta et al. 2009). Metabolism of arachidonic acid, a major component of animal fat, by cyclooxygenase (COX) generates prostaglandin and other eicosanoids, a group of biologically active lipids that play a key role in inflammation. Obesity is associated with elevated levels of COX-2 expression and heightened prostaglandin signaling (Subbaramaiah et al. 2012), suggesting a targetable inflammatory mechanism linking obesity and cancer. The anti-inflammatory properties of non-steroidal anti-inflammatory drugs (NSAIDs) are mediated via COX inhibition, which in turn reduces prostaglandin levels (Wang \& Dubois 2010). While the strongest evidence for a role for NSAIDs in chemoprevention comes from inverse associations with adenoma and colorectal cancer (Baron et al. 2003, Rostom et al. 2007), there is also support for a role for NSAIDs in other cancer types (Wang \& Dubois 2010).

While normal breast tissue expresses low levels of COX-2, $\sim 40 \%$ of invasive breast cancers overexpress this enzyme, and elevated levels are associated with increased risk of breast cancer-specific mortality (Ristimaki et al. 2002). The inverse association between NSAID use and breast cancer incidence does not appear to differ significantly by drug type, with similar effect estimates reported for both aspirin and non-aspirin NSAIDs (de Pedro et al. 2015). However, a randomized trial of low-dose aspirin failed to demonstrate an inverse association for breast cancer incidence (Cook et al. 2005), potentially suggesting that a higher dose may be required for chemoprevention. Some studies report that the protective association between NSAID use and breast cancer is limited to hormone receptor-positive disease (Terry et al. 2004, de Pedro et al. 2015), and others have reported a stronger inverse association between NSAID use and breast cancerspecific mortality in hormone receptor-positive cases (Allott et al. 2014a). Given that COX-2-mediated prostaglandin production promotes estrogen biosynthesis via upregulation of the aromatase pathway (Zhao et al. 1996), there is biologic rationale to support a role for NSAIDs in suppressing hormone receptor-positive breast cancer incidence and progression. Indeed, NSAID use is associated with reduced serum estradiol levels in women with breast cancer (Hudson et al. 2008), which may impact the growth of estrogen-responsive tumors. Finally, in further support of a true biologic association between NSAID use and breast cancer, there is evidence that longer duration of NSAID use is more protective for both breast cancer incidence (Terry et al. 2004) and breast cancer-specific mortality (Allott et al. 2014a).

Studies in breast cancer mouse models support a role for COX-2 in promoting tumor growth (Liu et al. 2001, Lyons et al. 2011) and for selective COX-2 inhibitors, including celecoxib, in inhibiting tumor growth

Published by Bioscientifica Ltd. 
(Chang et al. 2004). One study showed that celecoxib was most protective in HER2-expressing mouse models of breast cancer, via reduction of prostaglandin levels (Howe et al. 2002), indicating a potential role for COX-2 inhibition in preventing HER2-positive breast cancer. However, while COX-2 overexpression has been reported in HER2positive breast cancers in women (Ristimaki et al. 2002, Subbaramaiah et al. 2002), the impact of NSAID use on this tumor subtype has not been widely examined, perhaps due to the relatively low frequency of HER2-enriched breast cancers in the human population. Finally, a study in a rat model of breast cancer showed that NSAIDs were only effective in hormone-responsive tumors (Woditschka et al. 2008), supporting epidemiologic literature reporting stronger associations between NSAID use and hormone receptor-positive breast cancer risk and mortality.

Similar to breast cancer, there is evidence for overexpression of COX-2 in prostate cancer, relative to non-cancerous tissue or benign prostatic hyperplasia (Yoshimura et al. 2000), and elevated expression is associated with increased prostate cancer-specific mortality (Khor et al. 2007). A meta-analysis reported an inverse association between NSAID use and aggressive prostate cancer risk, which was strongest among aspirin users, particularly longer-duration aspirin users (Liu et al. 2014). However, a randomized trial of celecoxib for 4-6 weeks in patients with localized prostate cancer had no impact on prostaglandin levels in the prostate (Antonarakis et al. 2009), potentially suggesting an exposure period of insufficient length to impact prostate cancer biology. Interestingly, the association between aspirin use and aggressive prostate cancer incidence appears to differ by geographic region, with a significant protective effect evident in North American but not in European studies (Liu et al. 2014, Wang et al. 2014). Given that antiinflammatory agents such as NSAIDs can lower PSA levels (Chang et al. 2010), this geographic disparity in results may be attributable in part to differences in screening practices. However, one North American study where prostate cancer screening was largely independent of PSA testing reported that aspirin and NSAID use was associated with reduced risk of aggressive disease (Vidal et al. 2014), supporting a true biologic association between NSAID use and prostate cancer. Finally, a number of studies in the TRAMP mouse model of prostate cancer support a role for COX inhibition in prostate cancer chemoprevention, reporting that celecoxib reduced tumor size (Gupta et al. 2004), caused regression of mPIN lesions (Narayanan et al. 2004) and inhibited the development of adenocarcinoma in a dose-dependent fashion (Narayanan et al. 2006).
One limitation of many observational studies of NSAID use is incomplete capture of NSAID use information, with many studies focusing solely on aspirin or ibuprofen use, or on prescription NSAIDs only (Allott et al. 2014a, de Pedro et al. 2015). Incomplete NSAID use data may attenuate the association between NSAID use and cancer, since 'unexposed' individuals may have taken other types of NSAIDs that were not ascertained during data collection, especially given the widespread use of these drugs. In addition, confounding by indication is an important consideration in observational studies of NSAID use, as users may be more likely to have chronic conditions such as arthritis for which they are taking NSAIDs (Allott et al. 2014a). Finally, although epidemiologic and preclinical evidence supports a role for COX inhibition in chemoprevention, the clinical utility of selective COX-2 inhibitors is limited due to cardiovascular and gastrointestinal side effects (Wang \& Dubois 2010). As such, understanding the mechanisms linking NSAID use and cancer will result in the identification of additional biomarkers and therapeutic targets, potentially enabling the development of therapeutic agents with fewer side effects than existing COX inhibitors.

Hypercholesterolemia and statins Hypercholesterolemia, an obesity-associated co-morbidity, affects 20\% of the U.S. adult population (Fryar et al. 2012). Cholesterol is an essential plasma membrane component of animal cells and plays a crucial role in maintaining membrane fluidity, in addition to regulating intracellular signaling processes (Krycer \& Brown 2013). The role of cholesterol as the precursor for endogenous sex steroid biosynthesis suggests its potential importance in both breast and prostate cancer, two hormone-dependent tumor types.

Dietary cholesterol intake is associated with increased risk of breast cancer, with evidence for a dose-dependent effect across increasing quartiles of cholesterol intake (Hu et al. 2012). Moreover, a large prospective study of over one million adults in Korea showed that serum cholesterol levels were associated with increased risk of breast cancer (Kitahara et al. 2011). Consistent with the role of cholesterol as a precursor for sex steroid biosynthesis, studies that stratified by hormone receptor status reported that elevated serum cholesterol levels were associated with increased risk of hormone receptor-positive disease (Fagherazzi et al. 2010) and that high dietary cholesterol intake was associated with increased risk of ER-positive, but not ER-negative disease (Jakovljevic et al. 2002). Finally, a recent study demonstrated that 27-hydroxycholesterol (27-HC), the most abundant cholesterol

Published by Bioscientifica Ltd. 
metabolite in the circulation and an endogenous selective ER modulator (SERM), promoted ER-positive breast cancer progression in multiple mouse models (Nelson et al. 2013), suggesting a mechanistic link between cholesterol and breast cancer.

Relative to other organs of the body, normal prostate epithelial cells have high cholesterol content, and these levels increase further during progression to prostate cancer (Krycer \& Brown 2013), suggesting that cholesterol accumulation may be advantageous to prostate cancer progression. In support of this hypothesis, hypermethylation of the cholesterol efflux transporter ABCA1, an epigenetic silencing mechanism leading to accumulation of intratumoral cholesterol, has been associated with increased risk of aggressive prostate cancer (Lee et al. 2013). There is a suggestion that elevated cholesterol may be associated with increased risk of aggressive prostate cancer (Platz et al. 2008, Platz et al. 2009, Farwell et al. 2011, Mondul et al. 2011, Shafique et al. 2012) but not total prostate cancer (Platz et al. 2008, Mondul et al. 2010), although other studies have reported no association between cholesterol or its sub-fractions and prostate cancer risk (Martin et al. 2009, Jacobs et al. 2012). While studies examining prostate cancer progression are few, positive associations between elevated serum cholesterol levels and risk of prostate cancer recurrence (Allott et al. 2014b) and mortality (Batty et al. 2011) have been reported. In support of these epidemiologic associations, cholesterol has been shown to promote prostate cancer cell line growth in vitro and in vivo (Zhuang et al. 2002), while reduction of serum cholesterol levels lowered intratumoral androgen levels and slowed tumor growth in xenograft mouse models of human prostate cancer (Mostaghel et al. 2012), supporting the hypothesis that steroid biosynthesis may be an important mechanism linking cholesterol and prostate cancer.

Statins are cost-effective and widely prescribed cholesterol-lowering drugs with proven benefits for cardiovascular disease prevention (Ridker \& Cook 2013), and are used by approximately one in every four adults in the U.S. population ( $\mathrm{Gu}$ Q 2014). Statin use has been associated with reduced total cancer risk (Farwell et al. 2008) and lower cancer-specific mortality (Nielsen et al. 2012) via a number of potential mechanisms including mevalonate pathway inhibition (Pelton et al. 2012), reduced inflammation and angiogenesis (Pelton et al. 2012) and lower serum cholesterol levels (Demierre et al. 2005). Given that the bioavailability of statins in the circulation is low (Roy et al. 2011), their cholesterol-lowering properties may be the most relevant for breast and prostate cancers.
Despite biologic rationale for a role of statins in breast cancer chemoprevention, the majority of evidence supports no association between statin use and total breast cancer risk (Bonovas et al. 2005, Undela et al. 2012), and studies examining this association by breast cancer subtype are few. While one study reported reduced rates of ER-negative breast cancers among statin users (Kumar et al. 2008), another found a null association overall and no evidence of effect modification by hormone receptor status (Desai et al. 2013). However, epidemiologic evidence supports an inverse association between statin use and risk of breast cancer recurrence and mortality. Statin use after a breast cancer diagnosis has been associated with reduced risk of recurrence, with a stronger association for lipophilic statins (Kwan et al. 2008, Ahern et al. 2011). Furthermore, a study of over 30000 breast cancer cases in the Finnish Cancer Registry showed an inverse effect of both pre and post-diagnosis statin use on breast cancer-specific mortality, with evidence for a dose and time-dependent effect among pre-diagnosis users (Murtola et al. 2014). Another study in the UK Cancer Registry also reported a weak protective effect of statin use on breast cancer-specific mortality, with some evidence that simvastatin use showed the strongest association (Cardwell et al. 2015). Studies stratifying by hormone receptor status are required, as this information has been lacking in previous studies (Murtola et al. 2014, Cardwell et al. 2015).

In prostate cancer, while the preponderance of evidence does not support an association between statin use and total prostate cancer risk (Dale et al. 2006, Browning \& Martin 2007, Bonovas et al. 2008, Kuoppala et al. 2008, Bansal et al. 2012), an inverse association between statin use and risk of aggressive disease has been consistently reported (Bonovas et al. 2008, Bansal et al. 2012). Regarding prostate cancer outcomes after treatment, three meta-analyses have reported a null association between statin use and risk of recurrence (Mass et al. 2012, Park et al. 2013, Scosyrev et al. 2013). However, the studies contributing to these meta-analyses were few and most examined statin use at the time of prostate cancer treatment. Given the widespread use of statins, it is likely that many nonusers became statin users after treatment, which may bias the results of these previous studies towards the null. A retrospective analysis that minimized misclassification of statin users by excluding prevalent users at the time of prostate cancer treatment and capturing statin use throughout the follow-up period showed that post-diagnosis statin use was associated with reduced risk of recurrence (Allott et al. 2014c), suggesting

Published by Bioscientifica Ltd 
a true protective association between statin use and prostate cancer. Finally, an analysis of almost 12000 men with localized prostate cancer showed that postdiagnostic statin use was associated with reduced prostate cancer-specific mortality, with evidence for a stronger protective effect among those who had also used statins before diagnosis (Yu et al. 2014b). Given that cardiovascular disease and cancer are the two most common causes of mortality in the U.S. (American Society of Clinical 2014), understanding the potential role of cholesterol reduction for cancer prevention will have important public health impact.

\section{Transdisciplinary challenges facing obesity and cancer research}

Obesity is a complex and heterogeneous exposure, giving rise to a number of considerations and challenges for obesity and cancer research, particularly in translating findings from preclinical to population-based research, and vice versa.

First, inter-individual variation in adipose tissue distribution leads to challenges in defining obesity status for population-based research. BMI is a well-validated surrogate of overall obesity, with the important strength of being widely used, thus enabling inter-study comparisons (Allott et al. 2013a). However, visceral obesity accumulation of adipose tissue within the abdominal cavity - is a risk factor for cardiovascular disease (Neeland et al. 2013) and certain types of cancer, including breast and prostate (Pischon et al. 2008, Doyle et al. 2012). Population-based studies rely on waist circumference and waist-to-hip ratio as surrogates of visceral obesity, given that computed tomography (CT), the gold standard method for direct quantification of visceral fat area (VFA), is not feasible for population-based research. While these surrogate measures correlate more strongly with VFA than BMI does (Allott et al. 2014d), it is important to consider that they do not distinguish between subcutaneous and visceral adipose tissue at waist level (Fig. 4), potentially giving rise to some misclassification of visceral obesity status. Despite this limitation, waist circumference and waist-to-hip ratio offer advantages over BMI for estimating visceral obesity, given that these measures are less influenced by lean body mass. Of note, the prevalence of visceral obesity (measured by VFA or waist circumference) in the U.S. population is higher than that of overall obesity (measured by BMI), with $\sim 45 \%$ of men and women classified as viscerally obese by VFA (Pou et al. 2009), and 40\% of men and $60 \%$

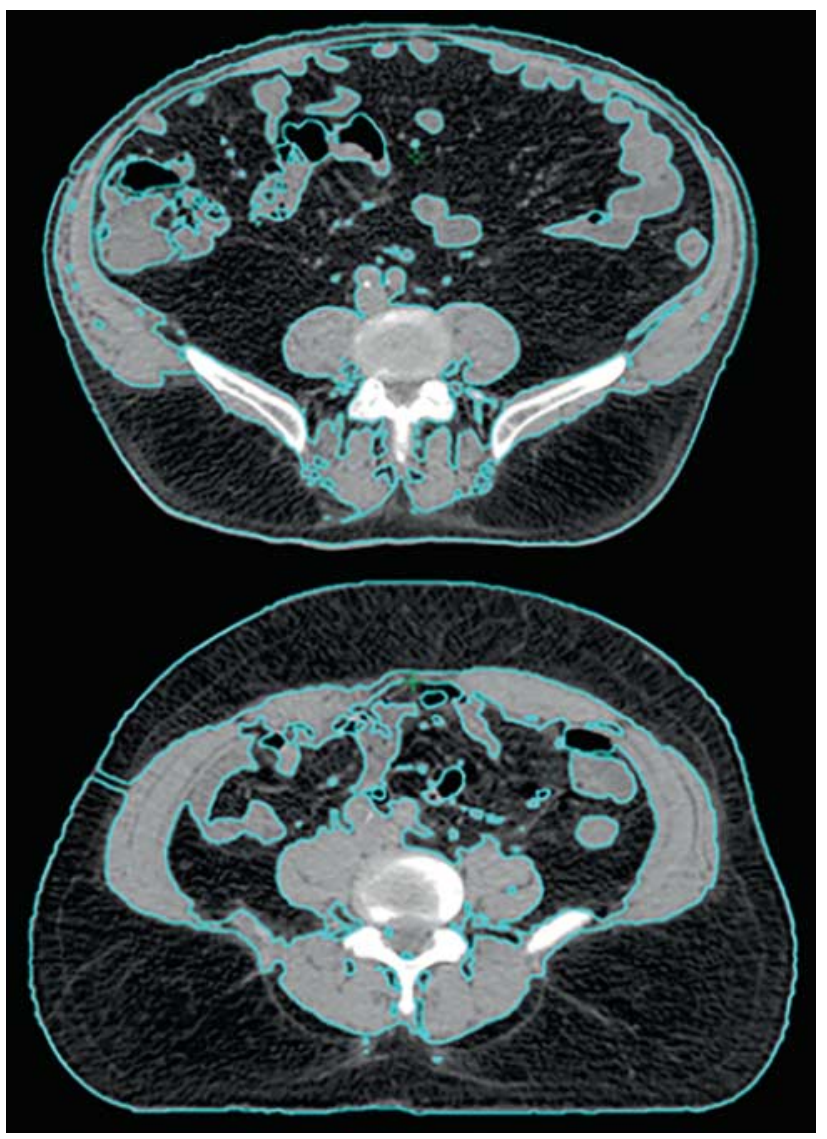

Figure 4

Computed tomography (CT) scans of two individuals with similar waist circumference (WC) but different amounts of visceral and subcutaneous fat area, illustrating the potential for misclassification when using WC as a surrogate of visceral obesity.

of women classified as viscerally obese by waist circumference (Li et al. 2007), while only one-third of individuals are classified as obese by BMI (Ogden et al. 2014). As such, defining obesity using BMI underestimates the prevalence of visceral obesity in the population. Moreover, roughly $20 \%$ of men and $10 \%$ of women with BMI $\geq 30 \mathrm{~kg} / \mathrm{m}^{2}$ do not have elevated VFA, while $\sim 10 \%$ of men and women with BMI $<30 \mathrm{~kg} / \mathrm{m}^{2}$ have elevated VFA (Pou et al. 2009). Misclassification of visceral obesity status contaminates the 'unexposed' (i.e., non-obese) group with 'exposed' individuals (i.e., viscerally obese) and vice versa, with the likely result of biasing associations between obesity and cancer towards the null (Fig. 5).

Second, adipose tissue is a unique organ in its ability to expand and contract throughout the life course of the individual, and the relevant timing or 'window of susceptibility' for obesity to impact tumor growth is unknown. Furthermore, population-based studies that

Published by Bioscientifica Ltd. 


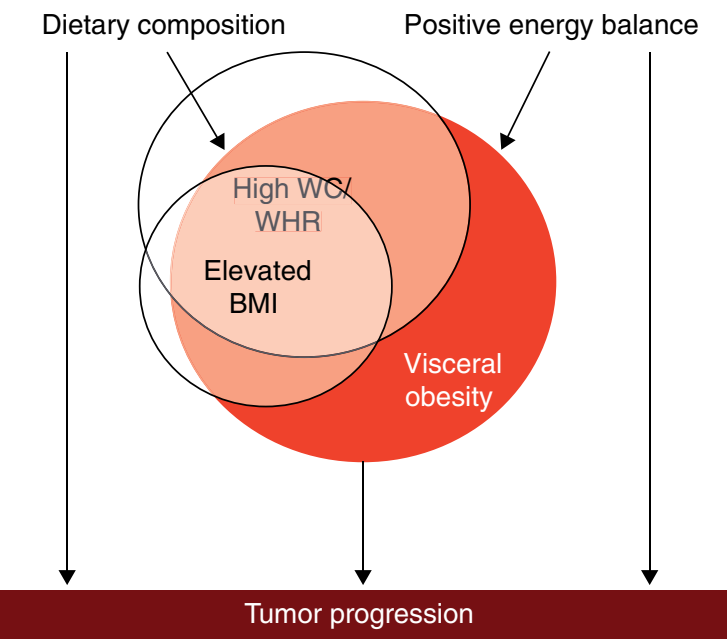

Figure 5

Challenges associated with studying obesity: defining the exposure and potential confounders.

examine weight change over the life course are usually limited to self-reported obesity status, and often require individuals to recollect their body weight many decades in the past. However, while self-reported weight is known to be systematically underreported, it remains predictive of obesity-associated co-morbidities and is not outperformed by corrected measures, indicating that it may be sufficient for population-based obesity and cancer research (Dutton $\&$ McLaren 2014). Another consideration is that population-based studies of weight change across the life course are limited both by relatively rare occurrences of weight loss and by unknown reasons for weight loss. As such, preclinical models provide an opportunity to evaluate the impact of diet-induced obesity and weight loss at different 'windows of susceptibility' over the life course of the mouse, for example, post pregnancy (Sundaram et al. $2014 b$ ). Careful design of preclinical studies with a consideration for timing of weight change in relation to tumor development will help to inform research questions in the population-based setting.

Finally, obesity is a heterogeneous phenotype, and it may be useful to consider it a disease comprised of distinct subtypes (Field et al. 2013). For example, individuals with elevated BMI may be further stratified according to visceral obesity, diabetes or metabolic syndrome status. This research approach may help us to determine, for example, whether high cholesterol or insulin resistance rather than obesity per se are the driving forces behind the obesitycancer link. Large, population-based studies with sufficient power for stratified analysis by various components of obesity are required for this approach. In addition, while pharmacoepidemiologic studies provide insight into potential chemopreventive properties of a number of medications that are widely used in the treatment of obesity-associated co-morbidities, these studies are subject to confounding by indication, in addition to other biases inherent in retrospective, observational studies of drug use. As such, results from population-based studies should be interpreted alongside preclinical findings, and alongside randomized controlled clinical trials.

\section{Conclusions}

The obesity-cancer link is of public health interest given the pervasiveness of both conditions, and the potentially modifiable nature of obesity. Although calorie restriction and weight loss are some of the most effective approaches for inhibiting tumor growth in animal models, weight loss is challenging for humans to achieve and maintain. Furthermore, observational data supporting a role for weight loss in cancer incidence and mortality in humans are lacking, and neither have clinical trials been conducted. While some epidemiologic and preclinical data suggest a chemopreventive role for agents targeting obesity-associated comorbidities, including metformin, NSAIDs and statins, not all studies support these findings and further research is needed. Given that preclinical models may be limited by their relevance to human cancers and observational studies are limited by nonrandomized design, integrating findings from different disciplines using a transdisciplinary approach may help us to gain insight into mechanisms linking obesity and cancer. An improved understanding of the mechanisms contributing to the obesity - cancer link will be important for cancer prevention and treatment efforts. In addition, given that the top five causes of mortality in the U.S. are heart disease, stroke, diabetes, kidney disease and cancer (Schmitz et al. 2013), targeting obesity is relevant not only to improve cancer-specific outcomes but also to impact all-cause mortality among cancer survivors.

\section{Declaration of interest}

The authors declare that there is no conflict of interest that could be perceived as prejudicing the impartiality of this review.

\section{Funding}

This work was supported by the National Cancer Institute (R35 CA197627, $\mathrm{SDH})$, the Breast Cancer Research Foundation (SDH) and the University Cancer Research Fund of North Carolina (EHA).

Published by Bioscientifica Ltd 


\section{References}

Adams TD, Stroup AM, Gress RE, Adams KF, Calle EE, Smith SC, Halverson RC, Simper SC, Hopkins PN \& Hunt SC 2009 Cancer incidence and mortality after gastric bypass surgery. Obesity $\mathbf{1 7}$ 796-802. (doi:10.1038/oby.2008.610)

Ahern TP, Pedersen L, Tarp M, Cronin-Fenton DP, Garne JP, Silliman RA, Sorensen HT \& Lash TL 2011 Statin prescriptions and breast cancer recurrence risk: a Danish nationwide prospective cohort study. Journal of the National Cancer Institute 103 1461-1468. (doi:10.1093/ jnci/djr291)

Akinyeke T, Matsumura S, Wang X, Wu Y, Schalfer ED, Saxena A, Yan W, Logan SK \& Li X 2013 Metformin targets c-MYC oncogene to prevent prostate cancer. Carcinogenesis 34 2823-2832. (doi:10.1093/carcin/ bgt307)

Allott EH, Masko EM \& Freedland SJ 2013a Obesity and prostate cancer: weighing the evidence. European Urology 63 800-809. (doi:10.1016/ j.eururo.2012.11.013)

Allott EH, Abern MR, Gerber L, Keto CJ, Aronson WJ, Terris MK, Kane CJ, Amling CL, Cooperberg MR, Moorman PG et al. 2013b Metformin does not affect risk of biochemical recurrence following radical prostatectomy: results from the SEARCH database. Prostate Cancer and Prostatic Diseases 16 391-397. (doi:10.1038/pcan.2013.48)

Allott EH, Tse CK, Olshan AF, Carey LA, Moorman PG \& Troester MA 2014a Non-steroidal anti-inflammatory drug use, hormone receptor status, and breast cancer-specific mortality in the Carolina Breast Cancer Study. Breast Cancer Research and Treatment 147 415-421. (doi:10.1007/ s10549-014-3099-z)

Allott EH, Howard LE, Cooperberg MR, Kane CJ, Aronson WJ, Terris MK, Amling CL \& Freedland SJ 2014b Serum lipid profile and risk of prostate cancer recurrence: results from the SEARCH Database. Cancer Epidemiology, Biomarkers \& Prevention 23 2349-2356. (doi:10.1158/ 1055-9965.EPI-14-0458)

Allott EH, Howard LE, Cooperberg MR, Kane CJ, Aronson WJ, Terris MK, Amling CL \& Freedland SJ 2014c Postoperative statin use and risk of biochemical recurrence following radical prostatectomy: Results from the SEARCH database. BJU International 114 661-666. (doi:10.1111/ bju.12720)

Allott EH, Howard LE, Song HJ, Sourbeer KN, Koontz BF, Salama JK \& Freedland SJ 2014d Racial differences in adipose tissue distribution and risk of aggressive prostate cancer among men undergoing radiotherapy. Cancer Epidemiology, Biomarkers \& Prevention 23 2404-2412. (doi:10.1158/1055-9965.EPI-14-0236)

Althuis MD, Fergenbaum JH, Garcia-Closas M, Brinton LA, Madigan MP \& Sherman ME 2004 Etiology of hormone receptor-defined breast cancer: a systematic review of the literature. Cancer Epidemiology, Biomarkers \& Prevention 13 1558-1568.

American Society of Clinical Oncology 2014 The state of cancer care in America 2014: a report by the American Society of Clinical Oncology. Journal of Oncology Practice 10 119-142. (doi:10.1200/JOP.2014.001386)

Amy NK, Aalborg A, Lyons P \& Keranen L 2006 Barriers to routine gynecological cancer screening for White and African-American obese women. International Journal of Obesity 30 147-155. (doi:10.1038/ sj.ijo.0803105)

Andersson SO, Wolk A, Bergstrom R, Adami HO, Engholm G, Englund A \& Nyren O 1997 Body size and prostate cancer: a 20-year follow-up study among 135006 Swedish construction workers. Journal of the National Cancer Institute 89 385-389. (doi:10.1093/jnci/89.5.385)

Anisimov VN, Egormin PA, Piskunova TS, Popovich IG, Tyndyk ML, Yurova MN, Zabezhinski MA, Anikin K IV, arkach AS \& Romanyukha AA 2010 Metformin extends life span of HER-2/neu transgenic mice and in combination with melatonin inhibits growth of transplantable tumors in vivo. Cell Cycle 9 188-197. (doi:10.4161/cc.9.1.10407)

Antonarakis ES, Heath EI, Walczak JR, Nelson WG, Fedor H, De Marzo AM, Zahurak ML, Piantadosi S, Dannenberg AJ, Gurganus RT, Phase et al.
2009 randomized, placebo-controlled trial of neoadjuvant celecoxib in men with clinically localized prostate cancer: evaluation of drug-specific biomarkers. Journal of Clinical Oncology 27 4986-4993. (doi:10.1200/JCO.2009.21.9410)

Arnold M, Pandeya N, Byrnes G, Renehan AG, Stevens GA, Ezzati M, Ferlay J, Miranda JJ, Romieu I, ikshit R et al. 2014 Global burden of cancer attributable to high body-mass index in 2012: a populationbased study. Lancet Oncology 16 36-46. (doi:10.1016/S1470-2045 (14)71123-4)

Ashrafian H, Ahmed K, Rowland SP, Patel VM, Gooderham NJ, Holmes E, Darzi A \& Athanasiou T 2011 Metabolic surgery and cancer: protective effects of bariatric procedures. Cancer 117 1788-1799. (doi:10.1002/ cncr.25738)

de Azambuja E, McCaskill-Stevens W, Francis P, Quinaux E, Crown JP, Vicente M, Giuliani R, Nordenskjold B, Gutierez J, ndersson M et al. 2010 The effect of body mass index on overall and disease-free survival in node-positive breast cancer patients treated with docetaxel and doxorubicin-containing adjuvant chemotherapy: the experience of the BIG 02-98 trial. Breast Cancer Research and Treatment 119 145-153. (doi:10.1007/s10549-009-0512-0)

Azoulay L, Dell'Aniello S, Gagnon B, Pollak M \& Suissa S 2011 Metformin and the incidence of prostate cancer in patients with type 2 diabetes. Cancer Epidemiology, Biomarkers \& Prevention 20 337-344. (doi:10.1158/ 1055-9965.EPI-10-0940)

Azrad M \& Demark-Wahnefried W 2014 The association between adiposity and breast cancer recurrence and survival: a review of the recent literature. Current Nutrition Reports 3 9-15. (doi:10.1007/s13668-0130068-9)

Banegas JR, Lopez-Garcia E, Gutierrez-Fisac JL, Guallar-Castillon P \& Rodriguez-Artalejo F 2003 A simple estimate of mortality attributable to excess weight in the European Union. European Journal of Clinical Nutrition 57 201-208. (doi:10.1038/sj.ejcn.1601538)

Banez LL, Hamilton RJ, Partin AW, Vollmer RT, Sun L, Rodriguez C, Wang Y, Terris MK, Aronson WJ, Presti JC Jr et al. 2007 Obesity-related plasma hemodilution and PSA concentration among men with prostate cancer. Journal of the American Medical Association 298 2275-2280. (doi:10.1001/jama.298.19.2275)

Bansal D, Undela K, D'Cruz S \& Schifano F 2012 Statin use and risk of prostate cancer: a meta-analysis of observational studies. PLOS ONE $\mathbf{7}$ e46691. (doi:10.1371/journal.pone.0046691)

Baron JA, Cole BF, Sandler RS, Haile RW, Ahnen D, Bresalier R, McKeown-Eyssen G, Summers RW, Rothstein R, Burke CA et al. 2003 A randomized trial of aspirin to prevent colorectal adenomas. New England Journal of Medicine 348 891-899. (doi:10.1056/ NEJMoa021735)

Bassett JK, Severi G, Baglietto L, Macinnis RJ, Hoang HN, Hopper JL, English DR \& Giles GG 2011 Weight change and prostate cancer incidence and mortality. International Journal of Cancer 131 1711-1719. (doi:10.1002/ijc.27414)

Batty GD, Kivimaki M, Clarke R, Davey Smith G \& Shipley MJ 2011 Modifiable risk factors for prostate cancer mortality in London: forty years of follow-up in the Whitehall study. Cancer Causes \& Control 22 311-318. (doi:10.1007/s10552-010-9691-6)

Befort CA, Klemp JR, Austin HL, Perri MG, Schmitz KH, Sullivan DK \& Fabian CJ 2012 Outcomes of a weight loss intervention among rural breast cancer survivors. Breast Cancer Research and Treatment 132 631-639. (doi:10.1007/s10549-011-1922-3)

Ben Sahra I, Laurent K, Loubat A, Giorgetti-Peraldi S, Colosetti P, Auberger P, Tanti JF, Le Marchand-Brustel Y \& Bost F 2008 The antidiabetic drug metformin exerts an antitumoral effect in vitro and in vivo through a decrease of cyclin D1 level. Oncogene 27 3576-3586. (doi:10.1038/sj.onc.1211024)

Ben Sahra I, Le Marchand-Brustel Y, Tanti JF \& Bost F 2010 Metformin in cancer therapy: a new perspective for an old antidiabetic drug? Molecular Cancer Therapeutics 9 1092-1099. (doi:10.1158/1535-7163. MCT-09-1186) 
Bensimon L, Yin H, Suissa S, Pollak MN \& Azoulay L 2014 The use of metformin in patients with prostate cancer and the risk of death. Cancer Epidemiology, Biomarkers \& Prevention 23 2111-2118. (doi:10.1158/ 1055-9965.EPI-14-0056)

Bergstrom A, Pisani P, Tenet V, Wolk A \& Adami HO 2001 Overweight as an avoidable cause of cancer in Europe. International Journal of Cancer 91 421-430. (doi:10.1002/1097-0215(200002)9999:9999<::AIDIJC1053 > 3.0.CO;2-T)

Berstein LM, Boyarkina MP, Tsyrlina EV, Turkevich EA \& Semiglazov VF 2011 More favorable progesterone receptor phenotype of breast cancer in diabetics treated with metformin. Medical Oncology 28 1260-1263. (doi:10.1007/s12032-010-9572-6)

Besic N, Satej N, Ratosa I, Horvat AG, Marinko T, Gazic B \& Petric R 2014 Long-term use of metformin and the molecular subtype in invasive breast carcinoma patients - a retrospective study of clinical and tumor characteristics. BMC Cancer 14 298. (doi:10.1186/1471-2407-14-298)

Bicakli DH, Varol U, Degirmenci M, Tunali D, Cakar B, Durusoy R, Karaca B, Ali Sanli U \& Uslu R 2014 Adjuvant chemotherapy may contribute to an increased risk for metabolic syndrome in patients with breast cancer. Journal of Oncology Pharmacy Practice pii 1078155214551315. (doi:10.1177/1078155214551315)

Blando J, Moore T, Hursting S, Jiang G, Saha A, Beltran L, Shen J, Repass J, Strom S \& DiGiovanni J 2011 Dietary energy balance modulates prostate cancer progression in Hi-Myc mice. Cancer Prevention Research 4 2002-2014. (doi:10.1158/1940-6207.CAPR-11-0182)

Bonanni B, Puntoni M, Cazzaniga M, Pruneri G, Serrano D, GuerrieriGonzaga A, Gennari A, Trabacca MS, Galimberti V, Veronesi P et al. 2012 Dual effect of metformin on breast cancer proliferation in a randomized presurgical trial. Journal of Clinical Oncology 30 2593-2600. (doi:10.1200/JCO.2011.39.3769)

Bonn SE, Wiklund F, Sjolander A, Szulkin R, Stattin P, Holmberg E, Gronberg H \& Balter K 2014 Body mass index and weight change in men with prostate cancer: progression and mortality. Cancer Causes \& Control 25 933-943. (doi:10.1007/s10552-014-0393-3)

Bonorden MJ, Rogozina OP, Kluczny CM, Grossmann ME, Grande JP, Lokshin A \& Cleary MP 2009 Cross-sectional analysis of intermittent versus chronic caloric restriction in the TRAMP mouse. Prostate 69 317-326. (doi:10.1002/pros.20878)

Bonorden MJ, Grossmann ME, Ewing SA, Rogozina OP, Ray A, Nkhata KJ, Liao DJ, Grande JP \& Cleary MP 2012 Growth and progression of TRAMP prostate tumors in relationship to diet and obesity. Prostate Cancer 2012 article 543970. (doi:10.1155/2012/543970)

Bonovas S, Filioussi K, Tsavaris N \& Sitaras NM 2005 Use of statins and breast cancer: a meta-analysis of seven randomized clinical trials and nine observational studies. Journal of Clinical Oncology 23 8606-8612. (doi:10.1200/JCO.2005.02.7045)

Bonovas S, Filioussi K \& Sitaras NM 2008 Statin use and the risk of prostate cancer: a metaanalysis of 6 randomized clinical trials and 13 observational studies. International Journal of Cancer 123 899-904. (doi:10.1002/ijc.23550)

Borowsky AD 2011 Choosing a mouse model: experimental biology in context - the utility and limitations of mouse models of breast cancer. Cold Spring Harbor Perspectives in Biology 3 a009670. (doi:10.1101/ cshperspect.a009670)

Boyle JP, Thompson TJ, Gregg EW, Barker LE \& Williamson DF 2010 Projection of the year 2050 burden of diabetes in the US adult population: dynamic modeling of incidence, mortality, and prediabetes prevalence. Population Health Metrics 8 29. (doi:10.1186/ 1478-7954-8-29)

Browning DR \& Martin RM 2007 Statins and risk of cancer: a systematic review and metaanalysis. International Journal of Cancer 120 833-843. (doi:10.1002/ijc.22366)

Buschemeyer WC III, Klink JC, Mavropoulos JC, Poulton SH, Demark-Wahnefried W, Hursting SD, Cohen P, Hwang D, Johnson TL \& Freedland SJ 2010 Effect of intermittent fasting with or without caloric restriction on prostate cancer growth and survival in SCID mice. Prostate 70 1037-1043. (doi:10.1002/pros.21136)

Cai H, Xu Z, Xu T, Yu B \& Zou Q 2014 Diabetes mellitus is associated with elevated risk of mortality amongst patients with prostate cancer: a meta-analysis of 11 cohort studies. Diabetes/Metabolism Research and Reviews 31 336-343. (doi:10.1002/dmrr.2582)

Calle EE, Rodriguez C, Walker-Thurmond K \& Thun MJ 2003 Overweight, obesity, and mortality from cancer in a prospectively studied cohort of U.S. adults. New England Journal of Medicine 348 1625-1638. (doi:10.1056/NEJMoa021423)

Campos-Gomez S, Valero V, Flores-Arredondo JH, Isassi-Chapa A, Rangel-Rodriguez I, Hortobagyi GN \& Gonzalez-Angulo AM 2014 Breast cancer subtype and baseline characteristics from diabetic breast cancer patients are not different from nondiabetics. Breast Journal 20 434-436. (doi:10.1111/tbj.12294)

Canchola AJ, Anton-Culver H, Bernstein L, Clarke CA, Henderson K, Ma H, Ursin G \& Horn-Ross PL 2012 Body size and the risk of postmenopausal breast cancer subtypes in the California Teachers Study cohort. Cancer Causes \& Control 23 473-485. (doi:10.1007/s10552-012-9897-x)

Cao Y \& Ma J 2011 Body mass index, prostate cancer-specific mortality, and biochemical recurrence: a systematic review and meta-analysis. Cancer Prevention Research 4 486-501. (doi:10.1158/1940-6207.CAPR-10-0229)

Cardwell CR, Hicks BM, Hughes C \& Murray LJ 2015 Statin use after diagnosis of breast cancer and survival: a population-based cohort study. Epidemiology 26 68-78. (doi:10.1097/EDE.0000000000000189)

Carmichael AR \& Bates T 2004 Obesity and breast cancer: a review of the literature. Breast 13 85-92. (doi:10.1016/j.breast.2003.03.001)

Centers for Disease Control \& Prevention 2011 Cancer survivors-United States, 2007. MMWR. Morbidity and Mortality Weekly Report 60 269-272.

Chamberlain C, Romundstad P, Vatten L, Gunnell D \& Martin RM 2011 The association of weight gain during adulthood with prostate cancer incidence and survival: a population-based cohort. International Journal of Cancer 129 1199-1206. (doi:10.1002/ijc.25739)

Chan DS, Vieira AR, Aune D, Bandera EV, Greenwood DC, McTiernan A, Navarro Rosenblatt D, Thune I, Vieira R \& Norat T 2014 Body mass index and survival in women with breast cancer-systematic literature review and meta-analysis of 82 follow-up studies. Annals of Oncology $\mathbf{2 5}$ 1901-1914. (doi:10.1093/annonc/mdu042)

Chang SH, Liu CH, Conway R, Han DK, Nithipatikom K, Trifan OC, Lane TF \& Hla T 2004 Role of prostaglandin E2-dependent angiogenic switch in cyclooxygenase 2-induced breast cancer progression. PNAS 101 591-596. (doi:10.1073/pnas.2535911100)

Chang SL, Harshman LC \& Presti JC Jr 2010 Impact of common medications on serum total prostate-specific antigen levels: analysis of the National Health and Nutrition Examination Survey. Journal of Clinical Oncology 28 3951-3957. (doi:10.1200/JCO.2009.27.9406)

Chu DI, De Nunzio C, Gerber L, Thomas JA II, Calloway EE, Albisinni S, Senocak C, McKeever MG, Moreira DM, Tubaro A et al. 2011 Predictive value of digital rectal examination for prostate cancer detection is modified by obesity. Prostate Cancer and Prostatic Diseases 14 346-353. (doi:10.1038/pcan.2011.31)

Cleary MP, Grande JP, Juneja SC \& Maihle NJ 2004 Diet-induced obesity and mammary tumor development in MMTV-neu female mice. Nutrition and Cancer 50 174-180. (doi:10.1207/s15327914nc5002_7)

Cleveland RJ, Eng SM, Abrahamson PE, Britton JA, Teitelbaum SL, Neugut AI \& Gammon MD 2007 Weight gain prior to diagnosis and survival from breast cancer. Cancer Epidemiology, Biomarkers \& Prevention 16 1803-1811. (doi:10.1158/1055-9965.EPI-06-0889)

Clyne M 2014 Prostate cancer: metformin - the new wonder drug? Nature Reviews. Urology 11 366. (doi:10.1038/nrurol.2014.136)

Colotta F, Allavena P, Sica A, Garlanda C \& Mantovani A 2009 Cancer-related inflammation, the seventh hallmark of cancer: links to genetic instability. Carcinogenesis 30 1073-1081. (doi:10.1093/carcin/ bgp127)

Cook NR, Lee IM, Gaziano JM, Gordon D, Ridker PM, Manson JE, Hennekens $\mathrm{CH} \&$ Buring JE 2005 Low-dose aspirin in the primary 
prevention of cancer: the Women's Health Study: a randomized controlled trial. Journal of the American Medical Association 294 47-55. (doi:10.1001/jama.294.1.47)

Cui Y, Whiteman MK, Flaws JA, Langenberg P, Tkaczuk KH \& Bush TL 2002 Body mass and stage of breast cancer at diagnosis. International Journal of Cancer 98 279-283. (doi:10.1002/ijc.10209)

Currie CJ, Poole CD \& Gale EA 2009 The influence of glucose-lowering therapies on cancer risk in type 2 diabetes. Diabetologia 52 1766-1777. (doi:10.1007/s00125-009-1440-6)

Currie CJ, Poole CD, Jenkins-Jones S, Gale EA, Johnson JA \& Morgan CL 2012 Mortality after incident cancer in people with and without type 2 diabetes: impact of metformin on survival. Diabetes Care 35 299-304. (doi:10.2337/dc11-1313)

Dale KM, Coleman CI, Henyan NN, Kluger J \& White CM 2006 Statins and cancer risk: a meta-analysis. Journal of the American Medical Association 295 74-80. (doi:10.1001/jama.295.1.74)

De Angel RE, Conti CJ, Wheatley KE, Brenner AJ, Otto G, Degraffenried LA \& Hursting SD 2013 The enhancing effects of obesity on mammary tumor growth and Akt/mTOR pathway activation persist after weight loss and are reversed by RAD001. Molecular Carcinogenesis 52 446-458. (doi:10.1002/mc.21878)

De Bruijn KM, Arends LR, Hansen BE, Leeflang S, Ruiter R \& van Eijck CH 2013 Systematic review and meta-analysis of the association between diabetes mellitus and incidence and mortality in breast and colorectal cancer. British Journal of Surgery 100 1421-1429. (doi:10.1002/bjs.9229)

Decensi A, Puntoni M, Goodwin P, Cazzaniga M, Gennari A, Bonanni B \& Gandini S 2010 Metformin and cancer risk in diabetic patients: a systematic review and meta-analysis. Cancer Prevention Research $\mathbf{3}$ 1451-1461. (doi:10.1158/1940-6207.CAPR-10-0157)

DeCensi A, Puntoni M, Gandini S, Guerrieri-Gonzaga A, Johansson HA, Cazzaniga M, Pruneri G, Serrano D, Schwab M, ofmann U et al. 2014 Differential effects of metformin on breast cancer proliferation according to markers of insulin resistance and tumor subtype in a randomized presurgical trial. Breast Cancer Research and Treatment 148 81-90. (doi:10.1007/s10549-014-3141-1)

Demierre MF, Higgins PD, Gruber SB, Hawk E \& Lippman SM 2005 Statins and cancer prevention. Nature Reviews. Cancer 5 930-942. (doi:10.1038/ nrc1751)

Desai P, Chlebowski R, Cauley JA, Manson JE, Wu C, Martin LW, Jay A, Bock C, Cote M, etrucelli N et al. 2013 Prospective analysis of association between statin use and breast cancer risk in the women's health initiative. Cancer Epidemiology, Biomarkers \& Prevention 22 1868-1876. (doi:10.1158/1055-9965.EPI-13-0562)

Dignam JJ, Wieand K, Johnson KA, Fisher B, Xu L \& Mamounas EP 2003 Obesity, tamoxifen use, and outcomes in women with estrogen receptor-positive early-stage breast cancer. Journal of the National Cancer Institute 95 1467-1476. (doi:10.1093/jnci/djg060)

Dogan S, Hu X, Zhang Y, Maihle NJ, Grande JP \& Cleary MP 2007 Effects of high-fat diet and/or body weight on mammary tumor leptin and apoptosis signaling pathways in MMTV-TGF-alpha mice. Breast Cancer Research 9 R91. (doi:10.1186/bcr1840)

Doyle SL, Donohoe CL, Lysaght J \& Reynolds JV 2012 Visceral obesity, metabolic syndrome, insulin resistance and cancer. Proceedings of the Nutrition Society 71 181-189. (doi:10.1017/S002966511100320X)

Dunlap SM, Chiao LJ, Nogueira L, Usary J, Perou CM, Varticovski L \& Hursting SD 2012a Dietary energy balance modulates epithelialto-mesenchymal transition and tumor progression in murine claudinlow and basal-like mammary tumor models. Cancer Prevention Research 5 930-942. (doi:10.1158/1940-6207.CAPR-12-0034)

Dutton DJ \& McLaren L 2014 The usefulness of 'corrected' body mass index vs. self-reported body mass index: comparing the population distributions, sensitivity, specificity, and predictive utility of three correction equations using Canadian population-based data. BMC Public Health 14 430. (doi:10.1186/1471-2458-14-430)

Eliassen AH, Colditz GA, Rosner B, Willett WC \& Hankinson SE 2006 Adult weight change and risk of postmenopausal breast cancer. Journal of the
American Medical Association 296 193-201. (doi:10.1001/jama. 296.2.193)

Ellwood-Yen K, Graeber TG, Wongvipat J, Iruela-Arispe ML, Zhang J, Matusik R, Thomas GV \& Sawyers CL 2003 Myc-driven murine prostate cancer shares molecular features with human prostate tumors. Cancer Cell 4 223-238. (doi:10.1016/S1535-6108(03)00197-1)

Evans JM, Donnelly LA, Emslie-Smith AM, Alessi DR \& Morris AD 2005 Metformin and reduced risk of cancer in diabetic patients. BMJ 330 1304-1305. (doi:10.1136/bmj.38415.708634.F7)

Fabian CJ, Kimler BF, Donnelly JE, Sullivan DK, Klemp JR, Petroff BK, Phillips TA, Metheny T, Aversman S, Yeh HW et al. 2013 Favorable modulation of benign breast tissue and serum risk biomarkers is associated with $>10 \%$ weight loss in postmenopausal women. Breast Cancer Research and Treatment 142 119-132. (doi:10.1007/ s10549-013-2730-8)

Fagan HB, Wender R, Myers RE \& Petrelli N 2011 Obesity and cancer screening according to race and gender. Journal of Obesity 2011218250. (doi:10.1155/2011/218250)

Fagherazzi G, Fabre A, Boutron-Ruault MC \& Clavel-Chapelon F 2010 Serum cholesterol level, use of a cholesterol-lowering drug, and breast cancer: results from the prospective E3N cohort. European Journal of Cancer Prevention 19 120-125. (doi:10.1097/CEJ.0b013e3283354918)

Farwell WR, Scranton RE, Lawler EV, Lew RA, Brophy MT, Fiore LD \& Gaziano JM 2008 The association between statins and cancer incidence in a veterans population. Journal of the National Cancer Institute $\mathbf{1 0 0}$ 134-139. (doi:10.1093/jnci/djm286)

Farwell WR, D'Avolio LW, Scranton RE, Lawler EV \& Gaziano JM 2011 Statins and prostate cancer diagnosis and grade in a veterans population. Journal of the National Cancer Institute 103 885-892. (doi:10.1093/jnci/djr108)

Field AE, Camargo CA Jr \& Ogino S 2013 The merits of subtyping obesity: one size does not fit all. Journal of the American Medical Association 310 2147-2148. (doi:10.1001/jama.2013.281501)

Finucane MM, Stevens GA, Cowan MJ, Danaei G, Lin JK, Paciorek CJ, Singh GM, Gutierrez HR, Lu Y, Bahalim AN et al. 2011 National, regional, and global trends in body-mass index since 1980: systematic analysis of health examination surveys and epidemiological studies with 960 country-years and 9.1 million participants. Lancet $\mathbf{3 7 7}$ 557-567. (doi:10.1016/S0140-6736(10)62037-5)

Ford NA, Lashinger LM, Allott EH \& Hursting SD 2013a Mechanistic targets and phytochemical strategies for breaking the obesity-cancer link. Frontiers in Oncology 3 209. (doi:10.3389/fonc.2013.00209)

Ford NA, Nunez NP, Holcomb VB \& Hursting SD 2013 $b$ IGF1 dependence of dietary energy balance effects on murine Met1 mammary tumor progression, epithelial-to-mesenchymal transition, and chemokine expression. Endocrine-Related Cancer 20 39-51. (doi:10.1530/ ERC-12-0329)

Franciosi M, Lucisano G, Lapice E, Strippoli GF, Pellegrini F \& Nicolucci A 2013 Metformin therapy and risk of cancer in patients with type 2 diabetes: systematic review. PLOS ONE 8 e71583. (doi:10.1371/journal. pone.0071583)

Freedland SJ, Terris MK, Presti JC Jr, Amling CL, Kane CJ, Trock B \& Aronson WJ 2004 Obesity and biochemical outcome following radical prostatectomy for organ confined disease with negative surgical margins. Journal of Urology 172 520-524. (doi:10.1097/01.ju. 0000135302.58378.ae)

Freedland SJ, Grubb KA, Yiu SK, Nielsen ME, Mangold LA, Isaacs WB, Epstein JI \& Partin AW 2005 Obesity and capsular incision at the time of open retropubic radical prostatectomy. Journal of Urology $\mathbf{1 7 4}$ 1798-1801. (doi:10.1097/01.ju.0000177077.53037.72)

Freedland SJ, Platz EA, Presti JC Jr, Aronson WJ, Amling CL, Kane CJ \& Terris MK 2006 Obesity, serum prostate specific antigen and prostate size: implications for prostate cancer detection. Journal of Urology 175 500-504. (doi:10.1016/S0022-5347(05)00162-X) 
Friedman AM, Hemler JR, Rossetti E, Clemow LP \& Ferrante JM 2012 Obese women's barriers to mammography and pap smear: the possible role of personality. Obesity 20 1611-1617. (doi:10.1038/oby.2012.50)

Fryar CD, Chen TC \& Li X 2012 Prevalence of uncontrolled risk factors for cardiovascular disease: United States, 1999-2010. NCHS Data Brief 1-8.

Fuentes-Mattei E, Velazquez-Torres G, Phan L, Zhang F, Chou PC, Shin JH, Choi HH, Chen JS, Zhao R, hen J et al. 2014 Effects of obesity on transcriptomic changes and cancer hallmarks in estrogen receptorpositive breast cancer. Journal of the National Cancer Institute 106 dju158. (doi:10.1093/jnci/dju158)

Galet C, Gray A, Said JW, Castor B, Wan J, Beltran PJ, Calzone FJ, Elashoff D, Cohen P \& Aronson WJ 2013 Effects of calorie restriction and IGF-1 receptor blockade on the progression of 22Rv1 prostate cancer xenografts. International Journal of Molecular Sciences 14 13782-13795. (doi:10.3390/ijms140713782)

Gandini S, Puntoni M, Heckman-Stoddard BM, Dunn BK, Ford L, DeCensi A \& Szabo E 2014 Metformin and cancer risk and mortality: a systematic review and meta-analysis taking into account biases and confounders. Cancer Prevention Research 7 867-885. (doi:10.1158/ 1940-6207.CAPR-13-0424)

Gaudet MM, Press MF, Haile RW, Lynch CF, Glaser SL, Schildkraut J, Gammon MD, Douglas Thompson W \& Bernstein JL 2011 Risk factors by molecular subtypes of breast cancer across a population-based study of women 56 years or younger. Breast Cancer Research and Treatment 130 587-597. (doi:10.1007/s10549-011-1616-x)

Giles ED, Wellberg EA, Astling DP, Anderson SM, Thor AD, Jindal S, Tan AC, Schedin PS \& Maclean PS 2012 Obesity and overfeeding affecting both tumor and systemic metabolism activates the progesterone receptor to contribute to postmenopausal breast cancer. Cancer Research $\mathbf{7 2}$ 6490-6501. (doi:10.1158/0008-5472.CAN-12-1653)

Giovannucci E, Harlan DM, Archer MC, Bergenstal RM, Gapstur SM, Habel LA, Pollak M, Regensteiner JG \& Yee D 2010 Diabetes and cancer: a consensus report. Diabetes Care 33 1674-1685. (doi:10.2337/ dc10-0666)

Goodwin PJ \& Pritchard KI 2010 Obesity and hormone therapy in breast cancer: an unfinished puzzle. Journal of Clinical Oncology 28 3405-3407. (doi:10.1200/JCO.2010.29.5113)

Goodwin PJ, Ennis M, Pritchard KI, Trudeau ME, Koo J, Taylor SK \& Hood N 2012 Insulin- and obesity-related variables in early-stage breast cancer: correlations and time course of prognostic associations. Journal of Clinical Oncology 30 164-171. (doi:10.1200/JCO.2011.36.2723)

Goodwin PJ, Segal RJ, Vallis M, Ligibel JA, Pond GR, Robidoux A, Blackburn GL, Findlay B, Gralow JR, ukherjee S et al. 2014 Randomized trial of a telephone-based weight loss intervention in postmenopausal women with breast cancer receiving letrozole: the LISA trial. Journal of Clinical Oncology 32 2231-2239. (doi:10.1200/JCO.2013.53.1517)

Griggs JJ, Mangu PB, Anderson H, Balaban EP, Dignam JJ, Hryniuk WM, Morrison VA, Pini TM, Runowicz CD, Rosner GL et al. 2012 Appropriate chemotherapy dosing for obese adult patients with cancer: American Society of Clinical Oncology clinical practice guideline. Journal of Clinical Oncology 30 1553-1561. (doi:10.1200/JCO.2011.39.9436)

Grubb RL III, Black A, Izmirlian G, Hickey TP, Pinsky PF, Mabie JE, Riley TL, Ragard LR, Prorok PC, Berg CD et al. 2009 Serum prostate-specific antigen hemodilution among obese men undergoing screening in the prostate, lung, colorectal, and ovarian cancer screening trial. Cancer Epidemiology, Biomarkers \& Prevention 18 748-751. (doi:10.1158/10559965.EPI-08-0938)

Gu Q P-RR, Burt VL \& Kit BK 2014 Prescription cholesterol-lowering medication use in adults aged 40 and over: United States, 2003-2012. NCHS Data Brief 1-8.

Gupta S, Adhami VM, Subbarayan M, MacLennan GT, Lewin JS, Hafeli UO, Fu P \& Mukhtar H 2004 Suppression of prostate carcinogenesis by dietary supplementation of celecoxib in transgenic adenocarcinoma of the mouse prostate model. Cancer Research 64 3334-3343. (doi:10.1158/0008-5472.CAN-03-2422)
Hakkak R, MacLeod S, Shaaf S, Holley AW, Simpson P, Fuchs G, Jo CH, Kieber-Emmons T \& Korourian S 2007 Obesity increases the incidence of 7,12-dimethylbenz(a)anthracene-induced mammary tumors in an ovariectomized Zucker rat model. International Journal of Oncology 30 557-563. (doi:10.3892/ijo.30.3.557)

Hardie DG \& Alessi DR 2013 LKB1 and AMPK and the cancer-metabolism link - ten years after. BMC Biology 11 36. (doi:10.1186/1741-7007-11-36)

Harvie M, Howell A, Vierkant RA, Kumar N, Cerhan JR, Kelemen LE, Folsom AR \& Sellers TA 2005 Association of gain and loss of weight before and after menopause with risk of postmenopausal breast cancer in the Iowa women's health study. Cancer Epidemiology, Biomarkers \& Prevention 14 656-661. (doi:10.1158/1055-9965.EPI-04-0001)

Harvie MN, Pegington M, Mattson MP, Frystyk J, Dillon B, Evans G, Cuzick J, Jebb SA, Martin B, Cutler RG et al. 2011 The effects of intermittent or continuous energy restriction on weight loss and metabolic disease risk markers: a randomized trial in young overweight women. International Journal of Obesity 35 714-727. (doi:10.1038/ijo. 2010.171)

He X, Esteva FJ, Ensor J, Hortobagyi GN, Lee MH \& Yeung SC 2012 Metformin and thiazolidinediones are associated with improved breast cancer-specific survival of diabetic women with HER2 + breast cancer. Annals of Oncology 23 1771-1780. (doi:10.1093/annonc/mdr534)

Herschkowitz JI, Simin K, Weigman VJ, Mikaelian I, Usary J, Hu Z, Rasmussen KE, Jones LP, Assefnia S, handrasekharan S et al. 2007 Identification of conserved gene expression features between murine mammary carcinoma models and human breast tumors. Genome Biology 8 R76. (doi:10.1186/gb-2007-8-5-r76)

Howe LR, Subbaramaiah K, Patel J, Masferrer JL, Deora A, Hudis C, Thaler HT, Muller WJ, Du B, Brown AM et al. 2002 Celecoxib, a selective cyclooxygenase 2 inhibitor, protects against human epidermal growth factor receptor 2 (HER-2)/neu-induced breast cancer. Cancer Research 62 5405-5407.

Hu J, La Vecchia C, de Groh M, Negri E, Morrison H, Mery L \& Canadian Cancer Registries Epidemiology Research Group 2012 Dietary cholesterol intake and cancer. Annals of Oncology 23 491-500. (doi:10.1093/annonc/mdr155)

Hu MB, Liu SH, Jiang HW, Bai PD \& Ding Q 2014 Obesity affects the biopsy-mediated detection of prostate cancer, particularly high-grade prostate cancer: a dose-response meta-analysis of 29,464 patients. PLOS ONE 9 e106677. (doi:10.1371/journal.pone.0106677)

Hudson AG, Gierach GL, Modugno F, Simpson J, Wilson JW, Evans RW, Vogel VG \& Weissfeld JL 2008 Nonsteroidal anti-inflammatory drug use and serum total estradiol in postmenopausal women. Cancer Epidemiology, Biomarkers \& Prevention 17 680-687. (doi:10.1158/ 1055-9965.EPI-07-2739)

Hursting SD, Smith SM, Lashinger LM, Harvey AE \& Perkins SN 2010 Calories and carcinogenesis: lessons learned from 30 years of calorie restriction research. Carcinogenesis 31 83-89. (doi:10.1093/carcin/bgp280)

Ioannides SJ, Barlow PL, Elwood JM \& Porter D 2014 Effect of obesity on aromatase inhibitor efficacy in postmenopausal, hormone receptorpositive breast cancer: a systematic review. Breast Cancer Research and Treatment 147 237-248. (doi:10.1007/s10549-014-3091-7)

Irwin ML 2014 Weight loss interventions and breast cancer survival: the time is now. Journal of Clinical Oncology 32 2197-2199. (doi:10.1200/ JCO.2014.56.4583)

Jacobs EJ, Stevens VL, Newton CC \& Gapstur SM 2012 Plasma total, LDL, and HDL cholesterol and risk of aggressive prostate cancer in the Cancer Prevention Study II Nutrition Cohort. Cancer Causes \& Control 23 1289-1296. (doi:10.1007/s10552-012-0006-y)

Jakovljevic J, Touillaud MS, Bondy ML, Singletary SE, Pillow PC \& Chang S 2002 Dietary intake of selected fatty acids, cholesterol and carotenoids and estrogen receptor status in premenopausal breast cancer patients. Breast Cancer Research and Treatment 75 5-14. (doi:10.1023/ A:1016588629495)

Published by Bioscientifica Ltd. 
Jemal A, Bray F, Center MM, Ferlay J, Ward E \& Forman D 2011 Global cancer statistics. CA: A Cancer Journal for Clinicians 61 69-90. (doi:10.3322/caac.20107)

Jiralerspong S, Kim ES, Dong W, Feng L, Hortobagyi GN \& Giordano SH 2013 Obesity, diabetes, and survival outcomes in a large cohort of early-stage breast cancer patients. Annals of Oncology 24 2506-2514. (doi:10.1093/annonc/mdt224)

Joshu CE, Mondul AM, Menke A, Meinhold C, Han M, Humphreys EB, Freedland SJ, Walsh PC \& Platz EA 2011 Weight gain is associated with an increased risk of prostate cancer recurrence after prostatectomy in the PSA era. Cancer Prevention Research 4 544-551. (doi:10.1158/ 1940-6207.CAPR-10-0257)

Kasper JS \& Giovannucci E 2006 A meta-analysis of diabetes mellitus and the risk of prostate cancer. Cancer Epidemiology, Biomarkers \& Prevention 15 2056-2062. (doi:10.1158/1055-9965.EPI-06-0410)

Kasper JS, Liu Y \& Giovannucci E 2009 Diabetes mellitus and risk of prostate cancer in the health professionals follow-up study. International Journal of Cancer 124 1398-1403. (doi:10.1002/ijc.24044)

Kaushik D, Karnes RJ, Eisenberg MS, Rangel LJ, Carlson RE \& Bergstralh EJ 2013 Effect of metformin on prostate cancer outcomes after radical prostatectomy. Urologic Oncology 32 43e1-43e7. (doi:10.1016/j.urolonc. 2013.05.005)

Kerlikowske K, Walker R, Miglioretti DL, Desai A, Ballard-Barbash R \& Buist DS 2008 Obesity, mammography use and accuracy, and advanced breast cancer risk. Journal of the National Cancer Institute 100 1724-1733. (doi:10.1093/jnci/djn388)

Keto CJ, Aronson WJ, Terris MK, Presti JC, Kane CJ, Amling CL \& Freedland SJ 2011 Obesity is associated with castration-resistant disease and metastasis in men treated with androgen deprivation therapy after radical prostatectomy: results from the SEARCH database. BJU International 110 492-498. (doi:10.1111/j.1464-410X.2011.10754.x)

Khor LY, Bae K, Pollack A, Hammond ME, Grignon DJ, Venkatesan VM, Rosenthal SA, Ritter MA, Sandler HM, Hanks GE et al. 2007 COX-2 expression predicts prostate-cancer outcome: analysis of data from the RTOG 92-02 trial. Lancet Oncology 8 912-920. (doi:10.1016/S14702045(07)70280-2)

Kitahara CM, Berrington de Gonzalez A, Freedman ND, Huxley R, Mok Y, Jee SH \& Samet JM 2011 Total cholesterol and cancer risk in a large prospective study in Korea. Journal of Clinical Oncology 29 1592-1598. (doi:10.1200/JCO.2010.31.5200)

Kobayashi N, Barnard RJ, Said J, Hong-Gonzalez J, Corman DM, Ku M, Doan NB, Gui D, Elashoff D, ohen P et al. 2008 Effect of low-fat diet on development of prostate cancer and Akt phosphorylation in the Hi-Myc transgenic mouse model. Cancer Research 68 3066-3073. (doi:10.1158/0008-5472.CAN-07-5616)

Kowall B, Stang A, Rathmann W \& Kostev K 2015 No reduced risk of overall, colorectal, lung, breast, and prostate cancer with metformin therapy in diabetic patients: database analyses from Germany and the UK. Pharmacoepidemiology and Drug Safety 24 865-874. (doi:10.1002/ pds.3823)

Krycer JR \& Brown AJ 2013 Cholesterol accumulation in prostate cancer: a classic observation from a modern perspective. Biochimica et Biophysica Acta 1835 219-229. (doi:10.1016/j.bbcan.2013.01.002)

Kumar AS, Benz CC, Shim V, Minami CA, Moore DH \& Esserman LJ 2008 Estrogen receptor-negative breast cancer is less likely to arise among lipophilic statin users. Cancer Epidemiology, Biomarkers \& Prevention 17 1028-1033. (doi:10.1158/1055-9965.EPI-07-0726)

Kuoppala J, Lamminpaa A \& Pukkala E 2008 Statins and cancer: a systematic review and meta-analysis. European Journal of Cancer $\mathbf{4 4}$ 2122-2132. (doi:10.1016/j.ejca.2008.06.025)

Kwan ML, Habel LA, Flick ED, Quesenberry CP \& Caan B 2008 Post-diagnosis statin use and breast cancer recurrence in a prospective cohort study of early stage breast cancer survivors. Breast Cancer Research and Treatment 109 573-579. (doi:10.1007/s10549-007-9683-8)
Larsson SC, Mantzoros CS \& Wolk A 2007 Diabetes mellitus and risk of breast cancer: a meta-analysis. International Journal of Cancer $\mathbf{1 2 1}$ 856-862. (doi:10.1002/ijc.22717)

Lashinger LM, Ford NA \& Hursting SD 2014 $a$ Interacting inflammatory and growth factor signals underlie the obesity-cancer link. Journal of Nutrition 144 109-113. (doi:10.3945/jn.113.178533)

Lashinger LM, Rossi EL \& Hursting SD 2014b Obesity and resistance to cancer chemotherapy: interacting roles of inflammation and metabolic dysregulation. Clinical Pharmacology and Therapeutics 96 458-463. (doi:10.1038/clpt.2014.136)

Lee BH, Taylor MG, Robinet P, Smith JD, Schweitzer J, Sehayek E, Falzarano SM, Magi-Galluzzi C, Klein EA \& Ting AH 2013 Dysregulation of cholesterol homeostasis in human prostate cancer through loss of ABCA1. Cancer Research 73 1211-1218. (doi:10.1158/0008-5472. CAN-12-3128)

Lega IC, Shah PS, Margel D, Beyene J, Rochon PA \& Lipscombe LL 2014 The effect of metformin on mortality following cancer among patients with diabetes. Cancer Epidemiology, Biomarkers \& Prevention 23 1974-1984. (doi:10.1158/1055-9965.EPI-14-0327)

Li C, Ford ES, McGuire LC \& Mokdad AH 2007 Increasing trends in waist circumference and abdominal obesity among US adults. Obesity $\mathbf{1 5}$ 216-224. (doi:10.1038/oby.2007.505)

Litton JK, Gonzalez-Angulo AM, Warneke CL, Buzdar AU, Kau SW, Bondy M, Mahabir S, Hortobagyi GN \& Brewster AM 2008 Relationship between obesity and pathologic response to neoadjuvant chemotherapy among women with operable breast cancer. Journal of Clinical Oncology 26 4072-4077. (doi:10.1200/JCO.2007.14.4527)

Liu CH, Chang SH, Narko K, Trifan OC, Wu MT, Smith E, Haudenschild C, Lane TF \& Hla T 2001 Overexpression of cyclooxygenase- 2 is sufficient to induce tumorigenesis in transgenic mice. Journal of Biological Chemistry 276 18563-18569. (doi:10.1074/jbc.M010787200)

Liu Y, Chen JQ, Xie L, Wang J, Li T, He Y, Gao Y, Qin X \& Li S 2014 Effect of aspirin and other non-steroidal anti-inflammatory drugs on prostate cancer incidence and mortality: a systematic review and meta-analysis. BMC Medicine 12 55. (doi:10.1186/1741-7015-12-55)

Liu J, Ramakrishnan SK, Khuder SS, Kaw MK, Muturi HT, Lester SG, Lee SJ, Fedorova LV, Kim AJ, Mohamed IE et al. 2015 High-calorie diet exacerbates prostate neoplasia in mice with haploinsufficiency of Pten tumor suppressor gene. Molecular Metabolism 4 186-198. (doi:10.1016/ j.molmet.2014.12.011)

Llaverias G, Danilo C, Wang Y, Witkiewicz AK, Daumer K, Lisanti MP \& Frank PG 2010 A Western-type diet accelerates tumor progression in an autochthonous mouse model of prostate cancer. American Journal of Pathology 177 3180-3191. (doi:10.2353/ajpath.2010.100568)

Lyman GH \& Sparreboom A 2013 Chemotherapy dosing in overweight and obese patients with cancer. Nature Reviews. Clinical Oncology 10 451-459. (doi:10.1038/nrclinonc.2013.108)

Lyman GH, Dale DC \& Crawford J 2003 Incidence and predictors of low dose-intensity in adjuvant breast cancer chemotherapy: a nationwide study of community practices. Journal of Clinical Oncology $\mathbf{2 1}$ 4524-4531. (doi:10.1200/JCO.2003.05.002)

Lyons TR, O'Brien J, Borges VF, Conklin MW, Keely PJ, Eliceiri KW, Marusyk A, Tan AC \& Schedin P 2011 Postpartum mammary gland involution drives progression of ductal carcinoma in situ through collagen and COX-2. Nature Medicine 17 1109-1115. (doi:10.1038/ $\mathrm{nm} .2416)$

Ma J, Li H, Giovannucci E, Mucci L, Qiu W, Nguyen PL, Gaziano JM, Pollak M \& Stampfer MJ 2008 Prediagnostic body-mass index, plasma C-peptide concentration, and prostate cancer-specific mortality in men with prostate cancer: a long-term survival analysis. Lancet Oncology 9 1039-1047. (doi:10.1016/S1470-2045(08)70235-3)

MacInnis RJ \& English DR 2006 Body size and composition and prostate cancer risk: systematic review and meta-regression analysis. Cancer Causes \& Control 17 989-1003. (doi:10.1007/s10552-006-0049-z)

Makari-Judson G, Braun B, Jerry DJ \& Mertens WC 2014 Weight gain following breast cancer diagnosis: Implication and proposed 
mechanisms. World Journal of Clinical Oncology 5 272-282.

(doi:10.5306/wjco.v5.i3.272)

Margel D, Urbach DR, Lipscombe LL, Bell CM, Kulkarni G, Austin PC \& Fleshner N 2013 Metformin use and all-cause and prostate cancerspecific mortality among men with diabetes. Journal of Clinical Oncology 31 3069-3075. (doi:10.1200/JCO.2012.46.7043)

Martin RM, Vatten L, Gunnell D, Romundstad P \& Nilsen TI 2009 Components of the metabolic syndrome and risk of prostate cancer: the HUNT 2 cohort, Norway. Cancer Causes \& Control 20 1181-1192. (doi:10.1007/s10552-009-9319-x)

Maruthur NM, Bolen S, Brancati FL \& Clark JM 2009 Obesity and mammography: a systematic review and meta-analysis. Journal of General Internal Medicine 24 665-677. (doi:10.1007/s11606-009-0939-3)

Mass AY, Agalliu I, Laze J \& Lepor H 2012 Preoperative statin therapy is not associated with biochemical recurrence after radical prostatectomy: our experience and meta-analysis. Journal of Urology 188 786-791. (doi:10.1016/j.juro.2012.05.011)

Merrick GS, Galbreath RW, Butler WM, Wallner KE, Allen ZA \& Adamovich E 2007 Obesity is not predictive of overall survival following permanent prostate brachytherapy. American Journal of Clinical Oncology 30 588-596. (doi:10.1097/COC.0b013e318068b506)

Michels KB, Solomon CG, Hu FB, Rosner BA, Hankinson SE, Colditz GA, Manson JE \& Nurses' Health S 2003 Type 2 diabetes and subsequent incidence of breast cancer in the Nurses' Health Study. Diabetes Care 26 1752-1758. (doi:10.2337/diacare.26.6.1752)

Millikan RC, Newman B, Tse CK, Moorman PG, Conway K, Dressler LG, Smith LV, Labbok MH, Geradts J, Bensen JT et al. 2008 Epidemiology of basal-like breast cancer. Breast Cancer Research and Treatment 109 123-139. (doi:10.1007/s10549-007-9632-6)

Mizuno NK, Rogozina OP, Seppanen CM, Liao DJ, Cleary MP \& Grossmann ME 2013 Combination of intermittent calorie restriction and eicosapentaenoic acid for inhibition of mammary tumors. Cancer Prevention Research 6 540-547. (doi:10.1158/1940-6207.CAPR-13-0033)

Moller E, Adami HO, Mucci LA, Lundholm C, Bellocco R, Johansson JE, Gronberg H \& Balter K 2013 Lifetime body size and prostate cancer risk in a population-based case-control study in Sweden. Cancer Causes \& Control 24 2143-2155. (doi:10.1007/s10552-013-0291-0)

Mondul AM, Clipp SL, Helzlsouer KJ \& Platz EA 2010 Association between plasma total cholesterol concentration and incident prostate cancer in the CLUE II cohort. Cancer Causes \& Control 21 61-68. (doi:10.1007/ s10552-009-9434-8)

Mondul AM, Weinstein SJ, Virtamo J \& Albanes D 2011 Serum total and HDL cholesterol and risk of prostate cancer. Cancer Causes \& Control 22 1545-1552. (doi:10.1007/s10552-011-9831-7)

Morgans AK, Fan KH, Koyama T, Albertsen PC, Goodman M, Hamilton AS, Hoffman RM, Stanford JL, Stroup AM, Resnick MJ et al. 2014 Influence of age on incident diabetes and cardiovascular disease among prostate cancer survivors receiving androgen deprivation therapy. Journal of Urology 193 1226-1231. (doi:10.1016/j.juro.2014.11.006)

Mostaghel EA, Solomon KR, Pelton K, Freeman MR \& Montgomery RB 2012 Impact of circulating cholesterol levels on growth and intratumoral androgen concentration of prostate tumors. PLoS ONE 7 e30062. (doi:10.1371/journal.pone.0030062)

Moyer VA \& U.S. Preventative Services Task Force 2012 Screening for prostate cancer: U.S. Preventive Services Task Force recommendation statement. Annals of Internal Medicine 157 120-134. (doi:10.7326/00034819-157-2-201207170-00459)

Munsell MF, Sprague BL, Berry DA, Chisholm G \& Trentham-Dietz A 2014 Body mass index and breast cancer risk according to postmenopausal estrogen-progestin use and hormone receptor status. Epidemiologic Reviews 36 114-136. (doi:10.1093/epirev/mxt010)

Murtola TJ, Tammela TL, Lahtela J \& Auvinen A 2008 Antidiabetic medication and prostate cancer risk: a population-based case-control study. American Journal of Epidemiology 168 925-931. (doi:10.1093/aje/ kwn190)
Murtola TJ, Visvanathan K, Artama M, Vainio H \& Pukkala E 2014 Statin use and breast cancer survival: a nationwide cohort study from Finland. PLOS ONE 9 e110231. (doi:10.1371/journal.pone.0110231)

Narayanan BA, Narayanan NK, Pittman B \& Reddy BS 2004 Regression of mouse prostatic intraepithelial neoplasia by nonsteroidal antiinflammatory drugs in the transgenic adenocarcinoma mouse prostate model. Clinical Cancer Research 10 7727-7737. (doi:10.1158/1078-0432. CCR-04-0732)

Narayanan BA, Narayanan NK, Pttman B \& Reddy BS 2006 Adenocarcina of the mouse prostate growth inhibition by celecoxib: downregulation of transcription factors involved in COX-2 inhibition. Prostate 66 257-265. (doi:10.1002/pros.20331)

Neeland IJ, Ayers CR, Rohatgi AK, Turer AT, Berry JD, Das SR, Vega GL, Khera A, McGuire DK, Grundy SM et al. 2013 Associations of visceral and abdominal subcutaneous adipose tissue with markers of cardiac and metabolic risk in obese adults. Obesity 21 E439-E447. (doi:10.1002/ oby.20135)

Nelson ER, Wardell SE, Jasper JS, Park S, Suchindran S, Howe MK, Carver NJ, Pillai RV, Sullivan PM, Sondhi V et al. 2013 27-Hydroxycholesterol links hypercholesterolemia and breast cancer pathophysiology. Science $\mathbf{3 4 2}$ 1094-1098. (doi:10.1126/science.1241908)

Nielsen SF, Nordestgaard BG \& Bojesen SE 2012 Statin use and reduced cancer-related mortality. New England Journal of Medicine $\mathbf{3 6 7}$ 1792-1802. (doi:10.1056/NEJMoa1201735)

Niraula S, Ocana A, Ennis M \& Goodwin PJ 2012 Body size and breast cancer prognosis in relation to hormone receptor and menopausal status: a meta-analysis. Breast Cancer Research and Treatment 134 769-781. (doi:10.1007/s10549-012-2073-x)

Nogueira LM, Dunlap SM, Ford NA \& Hursting SD 2012 Calorie restriction and rapamycin inhibit MMTV-Wnt-1 mammary tumor growth in a mouse model of postmenopausal obesity. Endocrine-Related Cancer 19 57-68. (doi:10.1530/ERC-11-0213)

Nunez NP, Perkins SN, Smith NC, Berrigan D, Berendes DM, Varticovski L, Barrett JC \& Hursting SD 2008 Obesity accelerates mouse mammary tumor growth in the absence of ovarian hormones. Nutrition and Cancer 60 534-541. (doi:10.1080/01635580801966195)

Ogden CL, Carroll MD, Kit BK \& Flegal KM 2014 Prevalence of childhood and adult obesity in the United States, 2011-2012. Journal of the American Medical Association 311 806-814. (doi:10.1001/jama. 2014.732)

Pape-Ansorge KA, Grande JP, Christensen TA, Maihle NJ \& Cleary MP 2002 Effect of moderate caloric restriction and/or weight cycling on mammary tumor incidence and latency in MMTV-Neu female mice. Nutrition and Cancer 44 162-168. (doi:10.1207/S15327914NC4402_07)

Park HS, Schoenfeld JD, Mailhot RB, Shive M, Hartman RI, Ogembo R \& Mucci LA 2013 Statins and prostate cancer recurrence following radical prostatectomy or radiotherapy: a systematic review and meta-analysis. Annals of Oncology 24 1427-1434. (doi:10.1093/annonc/mdt077)

Patel T, Hruby G, Badani K, Abate-Shen C \& McKiernan JM 2010 Clinical outcomes after radical prostatectomy in diabetic patients treated with metformin. Urology 76 1240-1244. (doi:10.1016/j.urology. 2010.03.059)

de Pedro M, Baeza S, Escudero MT, Dierssen-Sotos T, Gomez-Acebo I, Pollan M \& Llorca J 2015 Effect of COX-2 inhibitors and other non-steroidal inflammatory drugs on breast cancer risk: a meta-analysis. Breast Cancer Research and Treatment 149 525-536. (doi:10.1007/s10549-015-3267-9)

Pelton K, Freeman MR \& Solomon KR 2012 Cholesterol and prostate cancer. Current Opinion in Pharmacology 12 751-759. (doi:10.1016/ j.coph.2012.07.006)

Phipps AI, Malone KE, Porter PL, Daling JR \& Li CI 2008 Body size and risk of luminal, HER2-overexpressing, and triple-negative breast cancer in postmenopausal women. Cancer Epidemiology, Biomarkers \& Prevention 17 2078-2086. (doi:10.1158/1055-9965.EPI-08-0206)

Pischon T, Boeing H, Weikert S, Allen N, Key T, Johnsen NF, Tjonneland A, Severinsen MT, Overvad K, ohrmann S et al. 2008 Body size and risk of prostate cancer in the European prospective investigation into cancer

Published by Bioscientifica Ltd 
and nutrition. Cancer Epidemiology, Biomarkers \& Prevention 17 3252-3261. (doi:10.1158/1055-9965.EPI-08-0609)

Platz EA, Clinton SK \& Giovannucci E 2008 Association between plasma cholesterol and prostate cancer in the PSA era. International Journal of Cancer 123 1693-1698. (doi:10.1002/ijc.23715)

Platz EA, Till C, Goodman PJ, Parnes HL, Figg WD, Albanes D, Neuhouser ML, Klein EA, Thompson IM Jr \& Kristal AR 2009 Men with low serum cholesterol have a lower risk of high-grade prostate cancer in the placebo arm of the prostate cancer prevention trial. Cancer Epidemiology, Biomarkers \& Prevention 18 2807-2813. (doi:10.1158/ 1055-9965.EPI-09-0472)

Pou KM, Massaro JM, Hoffmann U, Lieb K, Vasan RS, O’Donnell CJ \& Fox CS 2009 Patterns of abdominal fat distribution: the Framingham Heart Study. Diabetes Care 32 481-485. (doi:10.2337/dc08-1359)

Preston MA, Riis AH, Ehrenstein V, Breau RH, Batista JL, Olumi AF, Mucci LA, Adami HO \& Sorensen HT 2014 Metformin use and prostate cancer risk. European Urology 66 1012-1020. (doi:10.1016/j.eururo. 2014.04.027)

Renehan AG 2009 Bariatric surgery, weight reduction, and cancer prevention. Lancet Oncology 10 640-641. (doi:10.1016/S1470-2045 (09)70170-6)

Renehan AG, Tyson M, Egger M, Heller RF \& Zwahlen M 2008 Body-mass index and incidence of cancer: a systematic review and meta-analysis of prospective observational studies. Lancet 371 569-578. (doi:10.1016/ S0140-6736(08)60269-X)

Ridker PM \& Cook NR 2013 Statins: new American guidelines for prevention of cardiovascular disease. Lancet 382 1762-1765. (doi:10.1016/S0140-6736(13)62388-0)

Ristimaki A, Sivula A, Lundin J, Lundin M, Salminen T, Haglund C, Joensuu H \& Isola J 2002 Prognostic significance of elevated cyclooxygenase-2 expression in breast cancer. Cancer Research 62 632-635.

Rodriguez C, Patel AV, Calle EE, Jacobs EJ, Chao A \& Thun MJ 2001 Body mass index, height, and prostate cancer mortality in two large cohorts of adult men in the United States. Cancer Epidemiology, Biomarkers \& Prevention 10 345-353.

Rodriguez C, Freedland SJ, Deka A, Jacobs EJ, McCullough ML, Patel AV, Thun MJ \& Calle EE 2007 Body mass index, weight change, and risk of prostate cancer in the Cancer Prevention Study II Nutrition Cohort. Cancer Epidemiology, Biomarkers \& Prevention 16 63-69. (doi:10.1158/ 1055-9965.EPI-06-0754)

Rodvold KA, Rushing DA \& Tewksbury DA 1988 Doxorubicin clearance in the obese. Journal of Clinical Oncology 6 1321-1327.

Rogozina OP, Nkhata KJ, Nagle EJ, Grande JP \& Cleary MP 2013 The protective effect of intermittent calorie restriction on mammary tumorigenesis is not compromised by consumption of a high fat diet during refeeding. Breast Cancer Research and Treatment 138 395-406. (doi:10.1007/s10549-013-2464-7)

Rosenberg LU, Einarsdottir K, Friman EI, Wedren S, Dickman PW, Hall P \& Magnusson C 2006 Risk factors for hormone receptor-defined breast cancer in postmenopausal women. Cancer Epidemiology, Biomarkers \& Prevention 15 2482-2488. (doi:10.1158/1055-9965.EPI-06-0489)

Rostom A, Dube C, Lewin G, Tsertsvadze A, Barrowman N, Code C Sampson M, Moher D \& Force USPST 2007 Nonsteroidal antiinflammatory drugs and cyclooxygenase- 2 inhibitors for primary prevention of colorectal cancer: a systematic review prepared for the U.S Preventive Services Task Force. Annals of Internal Medicine 146 376-389. (doi:10.7326/0003-4819-146-5-200703060-00010)

Roy M, Kung HJ \& Ghosh PM 2011 Statins and prostate cancer: role of cholesterol inhibition vs. prevention of small GTP-binding proteins. American Journal of Cancer Research 1 542-561.

Rundle AG \& Neugut AI 2009 Modeling the effects of obesity and weight gain on PSA velocity. Prostate 69 1573-1578. (doi:10.1002/pros.21005)

Scales CD Jr, Curtis LH, Norris RD, Schulman KA, Dahm P \& Moul JW 2007 Relationship between body mass index and prostate cancer screening in the United States. Journal of Urology 177 493-498. (doi:10.1016/ j.juro.2006.09.059)

Schmitz KH, Neuhouser ML, Agurs-Collins T, Zanetti KA, Cadmus-Bertram L, Dean LT \& Drake BF 2013 Impact of obesity on cancer survivorship and the potential relevance of race and ethnicity. Journal of the National Cancer Institute 105 1344-1354. (doi:10.1093/jnci/djt223)

Scosyrev E, Tobis S, Donsky H, Wu G, Joseph J, Rashid H \& Messing E 2013 Statin use and the risk of biochemical recurrence of prostate cancer after definitive local therapy: a meta-analysis of eight cohort studies. BJU International 111 E71-E77. (doi:10.1111/j.1464410X.2012.11527.x)

Shafique K, McLoone P, Qureshi K, Leung H, Hart C \& Morrison DS 2012 Cholesterol and the risk of grade-specific prostate cancer incidence: evidence from two large prospective cohort studies with up to 37 years' follow up. BMC Cancer 12 25. (doi:10.1186/1471-2407-12-25)

Siegel RL, Miller KD \& Jemal A 2015 Cancer statistics, 2015. CA: A Cancer Journal for Clinicians 65 5-29. (doi:10.3322/caac.21254)

Sjostrom L, Narbro K, Sjostrom CD, Karason K, Larsson B, Wedel H, Lystig T, Sullivan M, Bouchard C, arlsson B et al. 2007 Effects of bariatric surgery on mortality in Swedish obese subjects. New England Journal of Medicine 357 741-752. (doi:10.1056/NEJMoa066254)

Sjostrom L, Gummesson A, Sjostrom CD, Narbro K, Peltonen M, Wedel H, Bengtsson C, Bouchard C, Carlsson B, ahlgren S et al. 2009 Effects of bariatric surgery on cancer incidence in obese patients in Sweden (Swedish Obese Subjects Study): a prospective, controlled intervention trial. Lancet Oncology 10 653-662. (doi:10.1016/S14702045(09)70159-7)

Smith MR 2007 Obesity and sex steroids during gonadotropin-releasing hormone agonist treatment for prostate cancer. Clinical Cancer Research 13 241-245. (doi:10.1158/1078-0432.CCR-06-2086)

Sparano JA, Wang M, Zhao F, Stearns V, Martino S, Ligibel JA, Perez EA, Saphner T, Wolff AC, Sledge GW Jr et al. 2012 Obesity at diagnosis is associated with inferior outcomes in hormone receptor-positive operable breast cancer. Cancer 118 5937-5946. (doi:10.1002/cncr. 27527)

Srokowski TP, Fang S, Hortobagyi GN \& Giordano SH 2009 Impact of diabetes mellitus on complications and outcomes of adjuvant chemotherapy in older patients with breast cancer. Journal of Clinical Oncology 27 2170-2176. (doi:10.1200/JCO.2008.17.5935)

Stevens GA, Singh GM, Lu Y, Danaei G, Lin JK, Finucane MM, Bahalim AN, McIntire RK, Gutierrez HR, owan M et al. 2012 National, regional, and global trends in adult overweight and obesity prevalences. Population Health Metrics 10 22. (doi:10.1186/1478-7954-10-22)

Subbaramaiah K, Norton L, Gerald W \& Dannenberg AJ 2002 Cyclooxygenase- 2 is overexpressed in HER-2/neu-positive breast cancer: evidence for involvement of AP-1 and PEA3. Journal of Biological Chemistry 277 18649-18657. (doi:10.1074/jbc.M111415200)

Subbaramaiah K, Morris PG, Zhou XK, Morrow M, Du B, Giri D, Kopelovich L, Hudis CA \& Dannenberg AJ 2012 Increased levels of COX-2 and prostaglandin E2 contribute to elevated aromatase expression in inflamed breast tissue of obese women. Cancer Discovery 2 356-365. (doi:10.1158/2159-8290.CD-11-0241)

Suissa S \& Azoulay L 2012 Metformin and the Risk of Cancer: Time-related biases in observational studies. Diabetes Care 35 2665-2673. (doi:10.2337/dc12-0788)

Sundaram S, Freemerman AJ, Johnson AR, Milner JJ, McNaughton KK, Galanko JA, Bendt KM, Darr DB, Perou CM, Troester MA et al. 2013 Role of HGF in obesity-associated tumorigenesis: C3(1)-TAg mice as a model for human basal-like breast cancer. Breast Cancer Research and Treatment 142 489-503. (doi:10.1007/s10549-013-2741-5)

Sundaram S, Le TL, Essaid L, Freemerman AJ, Huang MJ, Galanko JA, McNaughton KK, Bendt KM, Darr DB, Troester MA et al. 2014a Weight loss reversed obesity-induced HGF/c-Met pathway and basal-like breast cancer progression. Frontiers in Oncology 4 175. (doi:10.3389/fonc. 2014. 00175) 
Sundaram S, Freemerman AJ, Galanko JA, McNaughton KK, Bendt KM, Darr DB, Troester MA \& Makowski L 2014b Obesity-mediated regulation of $\mathrm{HGF} / \mathrm{c}-\mathrm{Met}$ is associated with reduced basal-like breast cancer latency in parous mice. PLoS ONE 9 e111394. (doi:10.1371/ journal.pone.0111394)

Suzuki R, Orsini N, Saji S, Key TJ \& Wolk A 2009 Body weight and incidence of breast cancer defined by estrogen and progesterone receptor status - a meta-analysis. International Journal of Cancer $\mathbf{1 2 4}$ 698-712. (doi:10.1002/ijc.23943)

Tait S, Pacheco JM, Gao F, Bumb C, Ellis MJ \& Ma CX 2014 Body mass index, diabetes, and triple-negative breast cancer prognosis. Breast Cancer Research and Treatment 146 189-197. (doi:10.1007/s10549014-3002-y)

Terry MB, Gammon MD, Zhang FF, Tawfik H, Teitelbaum SL, Britton JA, Subbaramaiah K, Dannenberg AJ \& Neugut AI 2004 Association of frequency and duration of aspirin use and hormone receptor status with breast cancer risk. Journal of the American Medical Association 291 2433-2440. (doi:10.1001/jama.291.20.2433)

Thomas JA II, Antonelli JA, Lloyd JC, Masko EM, Poulton SH, Phillips TE, Pollak M \& Freedland SJ 2010 Effect of intermittent fasting on prostate cancer tumor growth in a mouse model. Prostate Cancer and Prostatic Diseases 13 350-355. (doi:10.1038/pcan.2010.24)

Thompson HJ \& McTiernan A 2011 Weight cycling and cancer: weighing the evidence of intermittent caloric restriction and cancer risk. Cancer Prevention Research 4 1736-1742. (doi:10.1158/1940-6207. CAPR-11-0133)

Thompson MD, Grubbs CJ, Bode AM, Reid JM, McGovern R, Bernard PS, Stijleman IJ, Green JE, Bennett C, Juliana MM et al. 2015 Lack of effect of metformin on mammary carcinogenesis in nondiabetic rat and mouse models. Cancer Prevention Research 8 231-239. (doi:10.1158/ 1940-6207.CAPR-14-0181-T)

Togawa K, Ma H, Sullivan-Halley J, Neuhouser ML, Imayama I, Baumgartner KB, Smith AW, Alfano CM, McTiernan A, allard-Barbash R et al. 2014 Risk factors for self-reported arm lymphedema among female breast cancer survivors: a prospective cohort study. Breast Cancer Research 16 414. (doi:10.1186/s13058-014-0414-x)

Tsai H, Keating NL, Van Den Eeden SK, Haque R, Cassidy-Bushrow AE, Yood MU, Smith MR \& Potosky AL 2014 Risk of diabetes among patients receiving primary androgen deprivation therapy for clinically localized prostate cancer. Journal of Urology 193 1956-1962. (doi:10.1016/j.juro.2014.12.027)

Tsilidis KK, Capothanassi D, Allen NE, Rizos EC, Lopez DS, van Veldhoven K, Sacerdote C, Ashby D, Vineis P, zoulaki I et al. 2014 Metformin does not affect cancer risk: a cohort study in the U.K. Clinical Practice Research Datalink analyzed like an intention-to-treat trial. Diabetes Care 37 2522-2532. (doi:10.2337/dc14-0584)

Tsilidis KK, Kasimis JC, Lopez DS, Ntzani EE \& Ioannidis JP 2015a Type 2 diabetes and cancer: umbrella review of meta-analyses of observational studies. BMJ 350 g7607. (doi:10.1136/bmj.g7607)

Tsilidis KK, Allen NE, Appleby PN, Rohrmann S, Nothlings U, Arriola L, Gunter MJ, Chajes V, Rinaldi S, omieu I et al. 2015b Diabetes mellitus and risk of prostate cancer in the European prospective investigation into cancer and nutrition. International Journal of Cancer 136 372-381. (doi:10.1002/ijc.28989)

Undela K, Srikanth V \& Bansal D 2012 Statin use and risk of breast cancer: a meta-analysis of observational studies. Breast Cancer Research and Treatment 135 261-269. (doi:10.1007/s10549-012-2154-x)

Vazquez-Martin A, Oliveras-Ferraros C \& Menendez JA 2009 The antidiabetic drug metformin suppresses HER2 (erbB-2) oncoprotein overexpression via inhibition of the mTOR effector p70S6K1 in human breast carcinoma cells. Cell Cycle 8 88-96. (doi:10.4161/cc.8.1.7499)

Vidal AC, Howard LE, Moreira DM, Castro-Santamaria R, Adriole GL \& Freedland SJ 2014 Aspirin, NSAID and risk of prostate cancer: results from the REDUCE study. Clinical Cancer Research 15 756-762. (doi:10.1158/1078-0432)
Vrieling A, Buck K, Kaaks R \& Chang-Claude J 2010 Adult weight gain in relation to breast cancer risk by estrogen and progesterone receptor status: a meta-analysis. Breast Cancer Research and Treatment 123 641-649. (doi:10.1007/s10549-010-1116-4)

Wang D \& Dubois RN 2010 Eicosanoids and cancer. Nature Reviews. Cancer 10 181-193. (doi:10.1038/nrc2809)

Wang S, Gao J, Lei Q, Rozengurt N, Pritchard C, Jiao J, Thomas GV, Li G, Roy-Burman P, Nelson PS et al. 2003 Prostate-specific deletion of the murine Pten tumor suppressor gene leads to metastatic prostate cancer. Cancer Cell 4 209-221. (doi:10.1016/S1535-6108(03)00215-0)

Wang X, Lin YW, Wu J, Zhu Y, Xu XL, Xu X, Liang Z, Hu ZH, Li SQ, Zheng XY et al. 2014 Meta-analysis of nonsteroidal anti-inflammatory drug intake and prostate cancer risk. World Journal of Surgical Oncology 12 304. (doi:10.1186/1477-7819-12-304)

Whitley BM, Moreira DM, Thomas JA, Aronson WJ, Terris MK, Presti JC Jr, Kane CJ, Amling CL \& Freedland SJ 2011 Preoperative weight change and risk of adverse outcome following radical prostatectomy: results from the Shared Equal Access Regional Cancer Hospital database. Prostate Cancer and Prostatic Diseases 14 361-366. (doi:10.1038/pcan. 2011.42)

Woditschka S, Haag JD, Mau B, Lubet RA \& Gould MN 2008 Chemopreventive effects of celecoxib are limited to hormonally responsive mammary carcinomas in the neu-induced retroviral rat model. Breast Cancer Research 10 R18. (doi:10.1186/bcr1864)

Wolters R, Schwentner L, Regierer A, Wischnewsky M, Kreienberg R \& Wockel A 2012 Endocrine therapy in obese patients with primary breast cancer: another piece of evidence in an unfinished puzzle. Breast Cancer Research and Treatment 131 925-931. (doi:10.1007/s10549-011-1874-7)

World Cancer Research Fund/American Institute for Cancer Research 2007 Food, Nutrition, Physical Activity, and the Prevention of Cancer: a Global Perspective. Washington DC: AICR.

Wright JL \& Stanford JL 2009 Metformin use and prostate cancer in Caucasian men: results from a population-based case-control study. Cancer Causes \& Control 20 1617-1622. (doi:10.1007/s10552-0099407-y)

Wright ME, Chang SC, Schatzkin A, Albanes D, Kipnis V, Mouw T, Hurwitz P, Hollenbeck A \& Leitzmann MF 2007 Prospective study of adiposity and weight change in relation to prostate cancer incidence and mortality. Cancer 109 675-684. (doi:10.1002/cncr. 22443)

Wu C, Aronson WJ, Terris MK, Presti JC Jr, Kane CJ, Amling CL \& Freedland SJ 2013 Diabetes predicts metastasis after radical prostatectomy in obese men: results from the SEARCH database. BJU International 111 E310-E318. (doi:10.1111/j.1464-410X.2012. 11687.x)

Xu H, Hu MB, Bai PD, Zhu WH, Ding Q \& Jiang HW 2014 Will metformin postpone high-fat diet promotion of TRAMP mouse prostate cancer development and progression? International Urology and Nephrology 46 2327-2334. (doi:10.1007/s11255-014-0823-x)

Yang XR, Chang-Claude J, Goode EL, Couch FJ, Nevanlinna H, Milne RL, Gaudet M, Schmidt MK, Broeks A, ox A et al. 2011 Associations of breast cancer risk factors with tumor subtypes: a pooled analysis from the Breast Cancer Association Consortium studies. Journal of the National Cancer Institute 103 250-263. (doi:10.1093/jnci/djq526)

Yoshimura R, Sano H, Masuda C, Kawamura M, Tsubouchi Y, Chargui J, Yoshimura N, Hla T \& Wada S 2000 Expression of cyclooxygenase-2 in prostate carcinoma. Cancer 89 589-596. (doi:10.1002/10970142(20000801)89:3 < 589::AID-CNCR14>3.0.CO;2-C)

Yu H, Yin L, Jiang X, Sun X, Wu J, Tian H, Gao X \& He X 2014a Effect of metformin on cancer risk and treatment outcome of prostate cancer: a meta-analysis of epidemiological observational studies. PLOS ONE 9 e116327. (doi:10.1371/journal.pone.0116327)

Yu O, Eberg M, Benayoun S, Aprikian A, Batist G, Suissa S \& Azoulay L $2014 b$ USe of statins and the risk of death in patients with prostate cancer. Journal of Clinical Oncology 32 5-11. (doi:10.1200/JCO.2013. 49.4757)

Published by Bioscientifica Ltd. 
Zhang F, Yang Y, Skrip L, Hu D, Wang Y, Wong C, Qiu J \& Lei H 2012 Diabetes mellitus and risk of prostate cancer: an updated meta-analysis based on 12 case-control and 25 cohort studies. Acta Diabetologica 49 S235-S246. (doi:10.1007/s00592-012-0439-5)

Zhang P, Li H, Tan X, Chen L \& Wang S 2013 Association of metformin use with cancer incidence and mortality: a metaanalysis. Cancer Epidemiology 37 207-218. (doi:10.1016/j.canep. 2012.12.009)

Zhang X, Zhou G, Sun B, Zhao G, Liu D, Sun J, Liu C \& Guo H 2015 Impact of obesity upon prostate cancer-associated mortality: a meta-analysis of 17 cohort studies. Oncology Letters 9 1307-1312. (doi:10.3892/ol.2014. 2841)
Zhao Y, Agarwal VR, Mendelson CR \& Simpson ER 1996 Estrogen biosynthesis proximal to a breast tumor is stimulated by PGE2 via cyclic AMP, leading to activation of promoter II of the CYP19 (aromatase) gene. Endocrinology 137 5739-5742. (doi:10.1210/endo.137.12. 8940410)

Zhou G, Myers R, Li Y, Chen Y, Shen X, Fenyk-Melody J, Wu M, Ventre J, Doebber T, Fujii N et al. 2001 Role of AMP-activated protein kinase in mechanism of metformin action. Journal of Clinical Investigation 108 1167-1174. (doi:10.1172/JCI13505)

Zhuang L, Lin J, Lu ML, Solomon KR \& Freeman MR 2002 Cholesterol-rich lipid rafts mediate akt-regulated survival in prostate cancer cells. Cancer Research 62 2227-2231.

Received in final form 24 August 2015

Accepted 15 September 2015

Made available online as an Accepted Preprint

15 September 2015
Published by Bioscientifica Ltd. 